Mission d'Aide au

Développement

des Economies Rurales

M

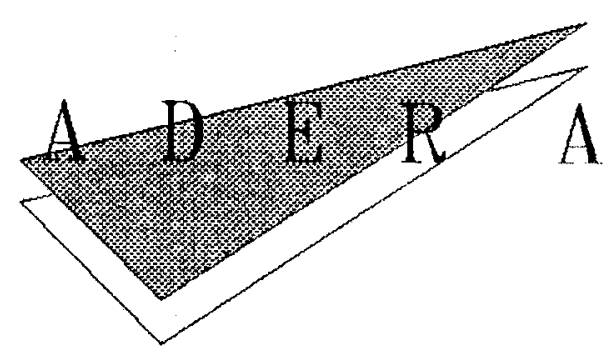

\title{
MADERA'S NURSERIES IN AFGHANISTAN PRESENT SITUATION AND FUTURE
}

\section{Henri Chaudet}

53-CII, Gul Mohar Lane, University Town, Peshawar, PAKISTAN.

UTPO Box 1440

Tel : (92-521) 45405

Fax : (92-521) 840234
September 1992

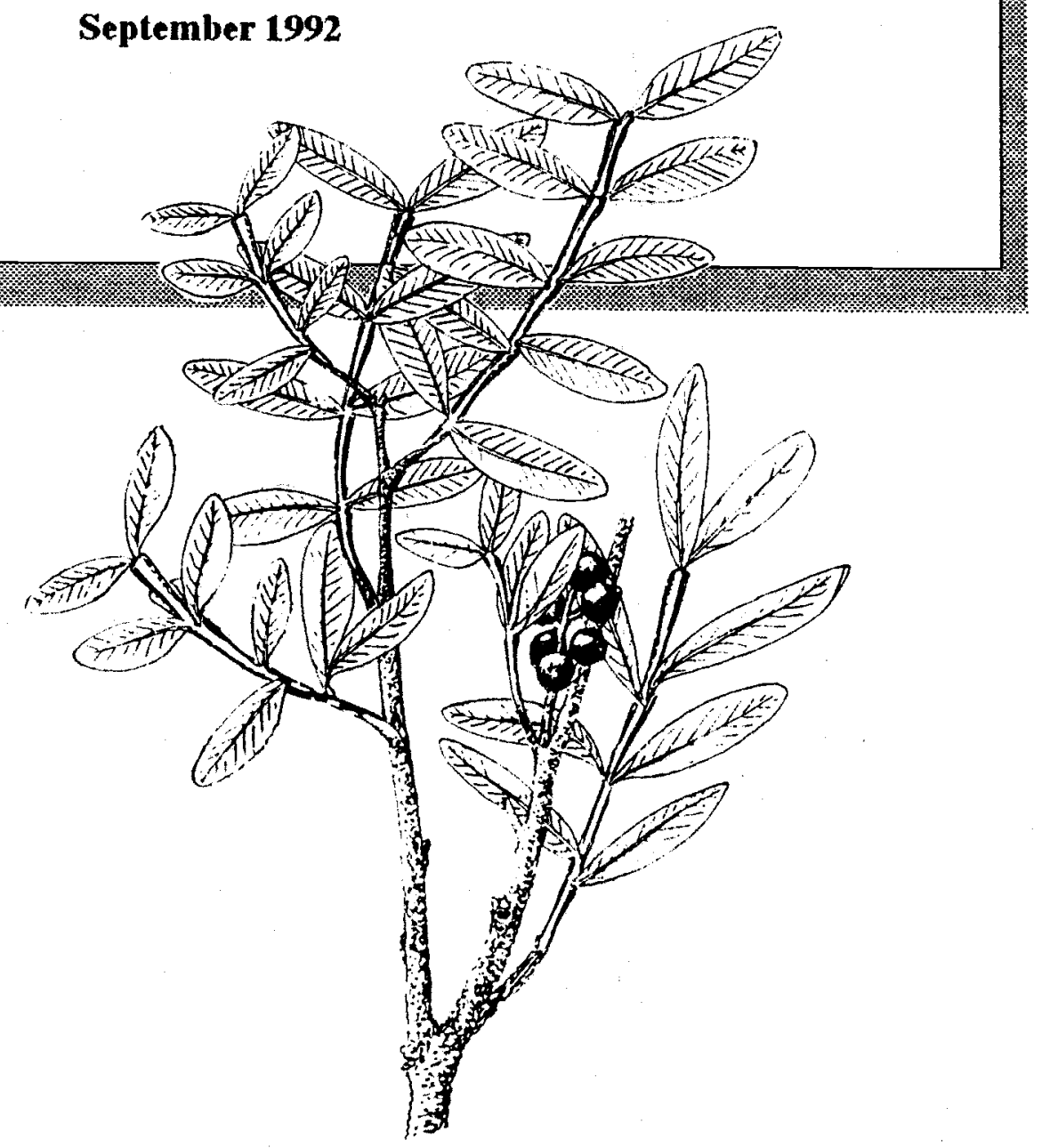

3, rue Roubo 750011 Paris, FRANCE. Tel : (33-1) 44648030 Fax : (33-1) 44648035 


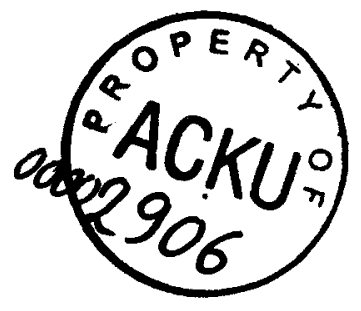

MADERA NURSERIES IN AFGHANISTAN

PRESENT SITUATION AND FUTURE

Henri Chaudet

September 1992 
FOREWORD

INTRODUCTION

EXECUTIVE SUMMARY

ii

CONTEXT

ii

EQUIPMENT OF THE NURSERIES

ii i

PLACE WITHIN MADERA'S PROGRAMS

iv

STAFF

PRODUCTION

iv

FOLLOW-UP

vii

COST PRICES

vii

PROF ITABILITY

vii

SUSTAINABILITY

viii

I - CONTEXT AND OBJECTIVES

II - GENERAL INTRODUCTION TO THE NURSERIES
A - Geographic characteristics
3
B - Land status
C - Finance
D - Place within MADERA's program

III PRODUCTION CONDITIONS
A - Limitations due to nursery size
B - Problems with expansion
C - Condition of the land
D - Availability of water
E - Tools

IV - STAFFING AND EXTENT OF ACTIVITIES 7
A - Size
B - Management $\quad 7$
C - Laborers 18
D - Land worked 18
E - Organizational aspects 18

V - POINTS CONCERNING FRUIT PLANT PRODUCTION 9

A - Different types of fruit plants 9

1 - Plants propagated from seeds 9

2 - Plants propagated from cuttings 9

3 - Grafted plants 9

B - Period of growth in the nurseries 9

$\begin{array}{lr}\text { C - Production potential } & 10\end{array}$

VI - NUMBERS OF PLANTS PRODUCED 11

A - 1992 distribution 11

B - Expected 1993 distribution $\quad 12$ 
VII - QUALITATIVE ASPECTS

A - Forest tree plants

B - Fruit tree plants

VIII - ORGANIZATIONAL ASPECTS

IX - FINANCIAL ASPECTS

A - Estimate of committed expenditure 16

B - Cost price of plants

$X$ - GOALS FOR IMPROVEMENT

A - Limiting the production cycle 18

1 - Changes to the timing of distribution 18

2 - Possible changes to the grafting period 19

B - The organization of production

XI - PROFitABility OBJECTIVE

A - Expenditure reduction $\quad 21$

B - Introduction of realistic prices 21

C - Expected results $\quad 22$

XII - PRIVATIZATION OBJECTIVE 23

A - Hypothesis 23

B - Preparatory activities $\quad 23$

C - Implementation $\quad 24$

1 - The takeover of the nurseries 24

2 - Production of plants at home 25

XIII - RECOMMENDATIONS 26

A - General recommendations $\quad 26$

1 - For a new horticultural sector 26

2 - Quality Control 26

3 - Efficiency and profitability 27

4 - Privatization 27

5 - Distribution and popularization 28

6 - Arboricultural expansion 28

7 - Integration and collaboration 28

B - Specific recommendations 29

1 - Affecting several nurseries 29

2 - Affecting one nursery 30

ANNEX I - NOTES ON SOME FRUIT TREE SPECIES 32

ANNEX 2 - NOTES ON THE TRANSPORT OF PLANT STOCK 35

$\begin{array}{ll}\text { ANNEX } 3 \text { - TABLES } & 36\end{array}$

TABLE 1 : MAIN CARACTERISTICS OF MADERA'S NURSERIES 37

TABLE 2 : PRODUCTION WORK PLAN FOR FRUIT TREES 38 
TABLE 3 : FOREST TREES DISTRIBUTED BY MADERA'S NURSERIES IN 1992

TABLE 4 : FRUIT TREES DISTRIBUTED BY MADERA'S NURSERIES IN 1992

TABLE 5 : AVERAGE NUMBERS OF TREES DISTRIBUTED PER VILLAGE FROM MADERA'S IN BEGINNING 1992

TABLE 6 : ESTIMATED AMOUNT OF TREES READY FOR DISTRIBUTION IN BEGINNING 1993

TABLE 7 A : 1991 OCCUPATION RATE OF THE TREES DISTRIBUTED IN SPRING 1992

TABLE 7 B : 1992 OCCUPATION RATE OF THE TREES READY FOR DISTRIBUTION IN SPRING 1993

TABLE 8 : ESTIMATED EXPENSES FOR YEAR 1992 AND COST PRICE OF THE TREES

TABLE 9 : EXAMPLE OF A PRODUCTION PLAN FOR A 7000 usable m2 NURSERY

TABLE 10 : STAFF COMPARED TO SURFACE IN MADERA'S NURSERIES

TABLE 11 : (A) COST PRICE OF TREES PRODUCED IN A NURSERY (B) INCOME ACCORDING TO THE PROPOSAL SET OF PRICE 


\section{MADERA FORESTRY PROJECTS \\ NURSERIES}

\section{LEGEND}

BAGHESALAR Nursery name

Chagha Saray Province center

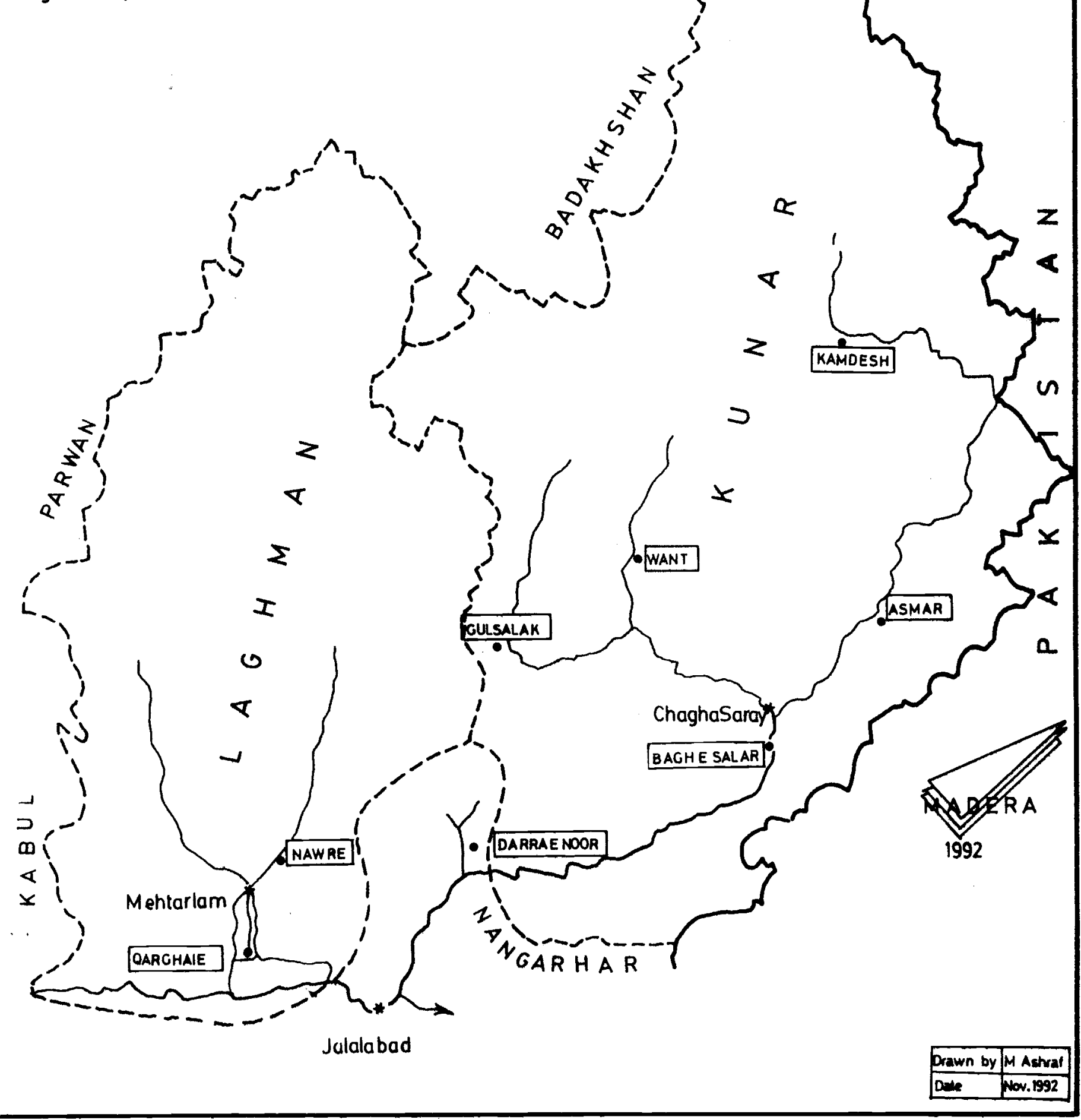


FOREWORD

As part of its rehabilitation and rural development programs in Afghanistan, over the last few years MADERA has set up or taken over eight forest and fruit trees nurseries, whose output is intended for local farmers.

This study tries to provide MADERA's management with an objective technical view of its nurseries' activities and to develop concrete proposals with a view to improving their efficiency. The information used to compile this report is the result of interviews made with nursery managers and farmers who have received trees. Data has also been provided by the Afghan Social Forestry Program, and by MADERA's accountability and evaluation cells.

This report therefore benefited from the help and time of many of MADERA's staff, including Messrs Olivier COSSEE, Bjorn RAKSTANG, Muhammad ISMAEL and Alain de BURES, all of whom have contributed in their own field. I would like to thank them all warmly for their cooperation.

Henri CHAUDET

Peshawar, 20/09/92 


\section{INTRODUCTION}

Henri CHAUDET is a nursery consultant for the French Ministry of Cooperation and has a long practical experience in Morocco and Mauritania. He stayed in Pakistan/Afghanistan for 4 months and carried two field surveys, visiting all of MADERA's nurseries.

The two questionnaires for nursery managers and for farmers were jointly prepared by Henri and the Evaluation Cell of MADERA. Both proved to be very long to go through, moreover because new questions were raised in the course of the interviews. The questionnaires would then rather be called checklists. The interviews were conducted by Henri and one expatriate with good knowledge of the area acting as a translator (either Alain de BURES or myself), because it was felt that the data accuracy would suffer if Afghan interviewers and translators were to be used. Each of the nursery managers interviews took a complete day to achieve. It was as an enriching experience for the nursery managers, giving them new prospects and ideas. Only the questionnaire for forestry managers has been translated in English and included here for reasons of time and space and because it has been the main source of information. Farmers answers were often biased by their wish to attract more assistance.

The French report and annexes 1 and 2 have been translated in English by Julie BOLGER, with much patience and care for the many technical words and the complex phrasing of Henri. Her translation was then checked again, but it is still possible that some small mistakes remain. The tables and checklist for nursery managers in annex 4 was translated by myself. I also prepared the executive summary, in an English that owes a lot to Julie's one but may certainly be faulty and misspellt here and there.

Henri's report is quite harch sometimes. In the summary I tried not to soften his words and to retain most of the report information. Of course the views expressed here are those of the consultant and MADERA's management and staff does not necessarily approved them. Nevertheless it is felt that this report comes close to genuine objectivity. It is worth noticing here that Henri worked on a volontary basis, nearly free of cost for MADERA, and that while here he made another mission and prepared another report for another NGO. All of us would like to convey our great respect and warm thanks to him. 


\section{EXECUTIVE SUMMÁRY}

\section{CONTEXT :}

As part of its rehabilitation and rural development programs in Afghanistan, over the last few years MADERA has set up or taken over eight fruit and forest trees nurseries. They are located in Kunar province (Asmar, Bagh Salar, Gulsalak, Kamdesh, Want), in Laghman province (Qarghay, Nawre) and in Nangahar province (Darra-e-Nur) at altitudes between 600 and $1,700 \mathrm{~m}$. Asmar, Gulsalak, Kamdesh, Want are complemented by a network of village micro-nurseries under the supervision of forestry extension agents. A ninth nursery is being set up at Bargamatal in the upper Kunar valley.

The forest trees meet with some indifference in the high valleys covered with conifers, but the populations living at a lower altitude, where wood is rarer, show a keen interest. Fruit trees are of great interest everywhere, fruit growing being a traditional practice (walnuts, mulberries, pomegranates, grapes and figs). Regularly planted orchards are few. Fruit trees are grown on the edge of cultivated fields, along irrigation channels or around dwellings, not usually well-spaced and are given no special care. Commerce is limited to wallnuts and dried mulberries.

The objectives of the nurseries should be first to refurnish orchards damaged by war and neglect, then to replace local species or varieties of lesser interest, and finally to create more regular orchards. Forest trees may mainly be planted along irrigation canals (poplar) and at the bottom of non-irrigated slopes (eucalyptus) along with drought resistant fruit trees (wild almond, pistachio and olive, caper, jujube). MADERA could undertake all or part of the costs of watering for the first 2 years, caretaking and the supply of plants. Grafting improved varieties onto these wild species is also worth trying.

The variety of ecological conditions should be studied in more depth in order to select the best species for any plantations. A simplified weather station, including a maximum-minimum thermometer and a direct-reading rain gauge should be installed in each nursery.

\section{EQUIPMENT OF THE NURSERIES :}

Asmar, Bagh Salar and Nawre suffered from neglect and inherited too many old trees which deplete their potential. They need to be gradually restored by using temporary staff. The budget for these staff should be used over 18 months to 2 years. It could be around 600 hours/jerib. The nursery managers should provide the program manager with a restoration plan and a timetable and justify their demands for laborers.

In Gulsalak, and Qarghay, wind breaks should be planted. Nawre and Qarghay have very compact soil which should be lightened by adding river sand and manure. 
No nursery lacks water throughout the year. The intake of the Bagh Salar canal on Pech river is often damaged, but the nursery's reservoir contains enough water to last until the canal is repaired. Multiplication plots should be transfered from the top terraces to ones below the reservoir and keep the higher terraces for plants which need less water (almond and jujube trees, rootstock collection, etc). MADERA should also look into the possibility of rehabilitating the water intake. It should be stressed that many farmers benefit from this canal.

In Want, a reservoir with a capacity of two cubic meters should be built to facilitate watering. It should be situated above all or part of the nursery, which could then be watered with a hose pipe.

The tools used in the nurseries are, on the whole, the same as that used by local farmers. They are not always appropriate for the techniques specific to nurseries. Tractors from chawki or Pech agricultural centers could be used in Bagh Salar in winter.

Gulsalak should be expanded on to nearby land. The present plot should be kept and used for collections of plants or for research. The poor soil needs a lot of organic manure.

\section{PLACE WITHIN MADERA'S PROGRAMS :}

Four nurseries are funded by the FAO (Bagh Salar, Asmar, Want, Kamdesh), the other ones are funded by the EEC. Those funded by FAO are managed by the Forestry sector of MADERA, and the others by the agricultural sector. They should all be concentrated in one sector and forestry would seem the most appropriate now. Eventually, a horticultural sector could cover fruit trees and vegetable productions.

Nurseries must improve their collaboration in terms of technical knowledge and plant stock. Collaboration between the nurseries and the agricultural centers should also be strengthened in the following areas: pest control, distribution of vegetable seeds, training and popularization. The production and distribution programs should be explained to MADERA's geographical managers.

Collaboration should be improved with the FAO and other NGOs working in the fields of nurseries. Competition between organizations should be avoided as the distribution of free plants and seedlings could undermine efforts at privatization.

\section{STAFF :}

The total personnel of the nurseries, management and laborers, is 20 for a total area of $36,350 \mathrm{~m} 2$. The staff are unequally distributed, ranging from 1 (at Gulsalak) to 4 (Asmar and Bagh Salar). The managers appointed by MADERA seem interested in their work and are 
enthusiastic extension workers. Some lack technical skills, particularly grafting. Training by the FAO should fill this gap. All have much to learn in exploiting the potential of their nurseries. Management training is a must in the near future, particularly in production plans and files keeping. At Qarghay and Nawre, one manager supervises the two nurseries. He wastes time traveling between the two and is unable to supervise either properly. A second manager should therefore be employed and the number of laborers reduced. At Want and Gulsalak the manager wish to be replaced whilst on mission, and could call on one of the forestry agents from the nearby villages.

The area worked by one laborer has been computed taking into account that the management staff are expected to carry out duties unrelated to production during half of his time. The results range from $465 \mathrm{~m} 2$ at Kamdesh (soon to be expanded), to 4,665 $\mathrm{m} 2$ at Bagh Salar. The average is around $2,425 \mathrm{~m} 2$, approximately half the accepted norm of one man to 2 to 2.5 jeribs $(4,000 / 5,000 \mathrm{~m} 2)$. The fact that nursery managers are still demanding more staff can be linked to 2 factors: 1) in Bagh Salar and Want, the junior staff recommended to MADERA lack diligence, but the managers do not have the authority to sanction or dismiss staff who enjoy powerful outside influences. 2) In Bagh Salar, Nawre, Qarghay and Want, perennial weeds (Cyperus conglomeratus, very difficult to eliminate by hand) are a time consuming problem. Spraying with 2-4D or plastic mulching should solve it.

Salaries are the largest budget head in the 4 nurseries funded by the FAO. It is therefore on personnel costs that MADERA can make the most substantial savings. This can be done in two ways: either by reducing the number of staff or by increasing the amount of land. The minimum workforce possible is one manager and one laborer (a workforce of 1.5 men), the minimum nursery size should therefore be $6,000 \mathrm{~m} 2$ ( 3 jeribs). The question of the future of smaller nurseries must be addressed as a priority, but any changes could only be implemented in stages.

Eventually, the proposed horticulture sector could be managed by an expatriate assisted by an Afghan counterpart, in order to guarantee the quality of production, ensure the supply of selected plant stock, support the nursery managers, promote the profitability of the nurseries and prepare for the privatization.

\section{PRODUCTION :}

In 1992, Asmar, Bagh Salar, Darra-e-Nur, Nawre and Want distributed 17,500 forest trees and 4,657 fruit trees produced in situ. Most of the forest trees are poplars and Leucaena, the bulk of it produced in Asmar. More than half of the fruit trees are made up of peach, vines and apple trees. Asmar and Bagh Salar distributed $3 / 4$ of them. The new nurseries, Gulsalak, Kamdesh and Qarghay, had not produced any plants for distribution. These numbers seem very low. Only Asmar, Bagh salar and Darra-e-Nur nurseries have distributed 
significant numbers of plants. The number of forest trees to be distributed in 1993 should be multiplied approximately by a factor of 4 and reach 70,900 plants. On the other hand, the number of fruit trees to be distributed will increase only of $42 \%$, reaching 6,630 trees. However, the number of fruit plants available will decrease at Asmar, Bagh Salar and Want.

The qualitative aspect is also worrying. In Want the bags for the cedars are too small, soil mixture, shade and watering are not suitable. Poplars are dense but it seems to produce satisfactory results. No problems are faced for fruit trees propagated by seeds and cuttings, but trees grafted with selected varieties (often provided by the FAO) must be of perfect quality. This has not been the case in 1992, at least in Asmar which distributed freshly grafted trees, with the following damaging consequences: 1) the graft will be very fragile and liable to damage whenever it is handled, and 2) there are no grafted plants available for distribution in 1993 .

In addition, Asmar has deliberately distributed ungrafted apple rootstocks. This failing is regrettable even if was caused by the farmers' impatience, as it can discredit MADERA. An attempt to rectify the situation has been made by undertaking a campaign to graft these trees on the farmers own property.

In terms of land utilization, the performance of MADERA's nurseries have been compared to norms computed as follow: space between rows: $90 \mathrm{~cm}$, space between plants: $15 \mathrm{~cm}$, maximum number of plants on one usable jerib (including $20 \%$ of small paths and channels): 12,600 plants. Taking into account losses (30\%) and the length of the production cycles, the following averages are suggested:

* Plants from seeds and cuttings:

* Grafted plants distributed in the autumn after two years in a nursery:

* Grafted plants distributed in spring, (occupying the land for 3 years)

8,400 plants/jerib/year

4,200 plants/jerib/year

2,800 plants/jerib/year

The comparison to these norms shows that the land utilization rate in MADERA's nurseries is variable but in general low and getting lower. However, some nurseries have produced good results (Asmar for its distributed production in 1992 and Gulsalak for the distribution forecast for 1993) which should be consolidated by improving the skills and experience of the nursery personnel.

To allow a shure supply of buds and cuttings from selected varieties, the nurseries shall gather carefully indexed collections of fruit trees (at least 3 of each variety). MADERA should experiment with a wide range of varieties even if this range is reduced by subsequent privatization. 
FOLLOW-UP :

The follow-up of plantings on farmers' own land should not only spread technical knowledge, but also enable to study the behavior of different varieties under different ecological conditions. Popularization should not be limited to technical advice on choice of species and their care. Advice should also be given on fruit preservation (the drying of apricots, mulberries, figs and grapes) and marketing.

\section{COST PRICES :}

The four nurseries funded by FAO have been studied in a financial point of view. A cost price of approximately Rs 8 to 9 per plant has been obtained. However, fruit trees in general cost more to produce than forest plants and have therefore been sold at Rs 2 each, against Rs 0.5 each for a forest plant in 1992 . If this ratio of 4 to 1 is applied, the average cost price of one fruit plant is around Rs 30 and that of a forest plant Rs 7.5. These prices are much higher than those charged by commercial nurseries in Pakistan where a grafted plant is sold at between Rs 10 and Rs 15. The cost price varies widely between nurseries, the lowest being at Bagh salar and Want. Such figures are not available for the other nurseries, but they are doubtless equally heterogenous and excessive.

\section{PROFITABILITY :}

MADERA's nurseries should aim to increase the number and the quality of the plants on offer. It is possible to increase the number of plants available to farmers by limiting the length of the production cycle and by better organizing production.

Distribution which is currently carried out towards the end of winter or at the beginning of spring, could be done at the end of the fall which is just as favorable for planting. The land would be free in November or December instead of in February or April of the following year, enabling a new cycle of production to be started. However, distribution at the end of winter should not be halted entirely since in the fall water is scarcer than in spring and it may be difficult to water the new plants.

Grafting could also be done at a different time of year. Currently done with the inverted $T$ technique in August or september on the first year of cultivation, as recommended by the FAO, its success rate is nearly $100 \%$. But other options should also been considered. Grafting can be done at the end of winter or at the beginning of spring using the chip-budding technique. This method is slightly less successful and more time-consuming than the inverted $T$. Inverted $T$ budding can also be carried out in March/April for cherry and apple trees and in May/June for apricot, almond, peach and plum trees. These techniques allow re-grafting on trees on which the fall grafting was unsuccessful. If they are not used, those trees will 
only be grafted the following summer and they will lose one year of the normal production cycle.

Each year a production plan must be prepared by each nursery manager and discussed with the program manager during the summer so that all selected plant stock required is known and can be communicated from September to the FAO, so they can supply them within the required time. The way to draw such a plan is explained in detail and an example is given.

The prices charged in 1992 were extremely low (Rs 0.5 per forest tree and Rs 2 per fruit tree) in order to encourage purchase. However, in order to make the nurseries profitable, prices which reflect actual production costs must be introduced. No more than 1 rupee per plant can be charged for forest plants or no-one will buy them. Ungrafted fruit trees should be charged Rs 3, and grafted fruit trees Rs 10 . These prices could be achieved in stages over 2 to 3 years. If in the same time the expenditures are decreased, the nurseries could become profitable. A 7,000 m2 nursery, employing 1,5 men (one manager and one laborer) and applying the above mention production plan, would cost Rs 161,000 to run and generate Rs 170,000 from trees sale, thus leaving a yearly surplus of Rs 9,000. For un-grafted fruit trees, the distance between rows can be reduced to $0.60 \mathrm{~m}$, which would enable 18,600 plants/usable jerib to be grown and, minus the losses, an annual production of 12,400 plants/usable jerib, (instead of 8,400 ). At Rs 3 per plant, this would mean an extra profit of Rs 12,000/jerib. The production of poplars, on the other hand, is not attractive. One jerib with 8,400 poplars at the unit price of Rs 1 makes an annual income of only Rs 8,400. The nurseries should therefore distribute cuttings rather than rooted trees, only keeping fewer mother-plants. Forest trees grown in bags are the most profitable for the amount of land used, but this production is limited by demand.

\section{SUSTAINABILITY :}

At some point MADERA will have to withdraw from the nurseries and this has to be prepared. The take over of the nurseries by the Afghan authorities is an attractive solution, but it assumes changes in the country which unfortunately seem unlikely to occur, and assumes that the Afghan authorities will be able and interested in taking over the system set up by MADERA. It seems sensible to seek other solutions.

The least problematic one would be to hand the nurseries over to the population, an process which would take many years, would oppose the population's reliance on external assistance and might also give Afghan staff, who see themselves as bureaucrats, a more realistic understanding of their position. The managers should particularly be convinced of the validity of this option before attempting to explain it to the rest of the staff and the local population. The nurseries must also gradually adopt private management practices and become profitable in order to attract private individuals. 
It should be possible to transfer a nursery to a private individual. The recommended minimum size would be between 2 and 3 jeribs which could be looked after by one man, supported by MADERA. This man will need sufficient capital to enable him to meet production costs and to wait for 10 months before receiving any income. He must have the necessary technical and management skills and be very wellmotivated. If this option is adopted, the present nursery managers have to select candidates and prepare them for the task ahead.

Another solution would be to encourage farmers with experience of grafting ("Paiwan Wala") or who will receive training at a MADERA nursery to diversify their income by producing small numbers of trees at home. Each MADERA nursery could provide dozens of farmers with apple tree rootstock, buds, plastic bags and forest tree seeds, as well as technical support. The farmers would either plant the trees or sell them to other farmers or to MADERA. This solution would be time-consuming for the nursery managers, but less risky than the other ones. It may also lead to the discovery of farmers willing and able to take over an existing nursery. MADERA's nurseries should try to improve the skills of traditional grafters or interested farmers by teaching them different grafting methods, how to take cuttings, pruning, etc. A way to do that could be to seek the hire local people at grafting time in the nurseries. 
I - CONTEXT AND OBJECTIVES

The implementation of a network of tree nurseries by MADERA in Afghanistan meets two objectives :

- To reduce the current destruction of the forest stock in the province by promoting its sustainable and healthy management and encouraging rural communities to contribute voluntarily to environmental protection and afforestation.

- To offer fruit plants of species and varieties adapted to their environment to farmers, enabling them to replant orchards ruined by neglect or war damage, to diversify production, to improve their nutrition and eventually to profit from their surplus production.

The first objective has met with some indifference from populations living close to the natural conifer forests of the high valleys, as they see no need to care for a resource which nature has always provided and renewed. This population is reluctant to take part in activities such as tree-planting, as this involves an immediate investment for uncertain and remote results.

On the other hand, the populations living at a lower altitude, where wood is rarer, show a keen interest in the distribution of trees such as eucalyptus, poplar, etc, because they meet their needs for firewood and construction material. The second objective is also better integrated with the socio-cultural context. Indeed, the population do not merely harvest wild fruits such as Diospyros sp. (persimmon), Ziziphus lotus (jujube), Pinus gerardiana (which produces a valuable kernel called Jalghoza) or Reptonia buxifolia (gorgureh) ; fruit growing is a traditional practice in the valleys of Kunar, as well as elsewhere in Afghanistan, with walnuts, mulberries, pomegranates, grapes and figs the main products.

In most villages there is at least one skilled grafter, a "Paiwan Wala" in Pushtu who performs grafting on demand and free of charge, and knows the good fruit trees from which he can take scions for free. They use the budding technique on apricot, citrus, almond, mulberry, walnut, peach, apple and plum trees. The war may have restricted if not discupted their activities, but they can still be found and still practice their skills. MADERA can play a role in reactivating and improving these networks of grafters.

Regularly planted orchards are only found occasionally. Fruit trees, when they are planted (most are the result of self-seeded plants left to grow where they appear), are placed on the edge of cultivated fields, along irrigation channels and paths or around dwellings. The trees are not usually well-spaced and are given no special care. At high altitudes, however, the walnut is a cash crop which provides a good income and is grown in cultivated fields. Mulberries are eaten fresh and are widely sold dried. Grapes and pomegranates are only consumed fresh. 
Fruit trees are of great interest everywhere. The fruit trees produced by MADERA's nurseries should at first be used to fill in gaps in existing orchards, then to replace species or varieties of lesser interest, which are the most common in cultivated areas at the moment. The possibility of creating more regularly planted orchards should be considered.

Forest trees will mainly be planted along irrigation canals (poplar) and at various sites where water is in shorter supply (eucalyptus). It also seems feasible to plant drought-resistant fruit or forest trees such as almond, caper, eucalyptus, jujube, olive and wild pistachio at the bottom of non-irrigated slopes (depending on the soil quality and coverage), which are now covered by scrub. Grafting improved species and varieties onto these wild varieties should also be worth trying, especially for persimmon and pistachio trees. Lastly, rows and groups of trees for decoration can be planted in towns and villages. 


\section{II - GENERAL INTRODUCTION TO THE NURSERIES}

MADERA's forest and fruit tree nurseries are spread over three provinces on the meridional slope of the Hindu Kush massif, in the north eastern part of Afghanistan.

In Kunar province:

- Asmar

- Bagh Salar

- Gulsalak

- Kamdesh

- Want

In Laghman province:

- Qarghay

- Nawre

In Nangahar province:

- Amla (Darra-e-Nur)

Those in the high valleys (Asmar, Gulsalak, Kamdesh, Want) are complemented by a network of village micro-nurseries (under the supervision of a forestry agent, who basically acts as an animator). Finally, a ninth nursery is being set up at Bargamatal in the upper Kunar valley (see map).

\section{A - Geographic characteristics}

The main facts concerning these nurseries are summarized in table I. All are situated on valley floors where agricultural activities are concentrated, due to the availability of both cultivable soil and water. All are on man-made terraces. As land is at a premium, particularly in the upper parts of the valleys, the surface area of the terraces is only 700 to $14,000 \mathrm{~m} 2$, and it is almost impossible to expand them.

The nurseries are situated at altitudes between 600 and $1,700 \mathrm{~m}$. The variety of ecological conditions should be studied in more depth. The conditions in the zones where the trees produced can flourish should also be better understood, in order to benefit all MADERA's horticultural and agricultural activities.

\section{B - Land status}

The land on which the nurseries are situated is either private property placed at MADERA's disposal for a fee (Darra-e-Nur, Nawre, Want) or free of charge (Gulsalak and Kamdesh) or land belonging to the state leased to MADERA without any financial obligation (Asmar, Bagh Salar, Qarghay). 


\section{C - Finance}

Four nurseries are funded by the FAO; Asmar, Bagh Salar, Kamdesh and want. FAO's input also covers valuable support in the form of selected plant stocks, grafted trees which can be distributed immediately, rootstock, etc. The Darra-e-Nur, Gulsalak, Nawre and Qarghay nurseries are included in an EEC funded program. Split funding of a program is not unusual and does not cause any particular inconvenience to MADERA.

\section{D - Place within MADERA's program}

The main difficulty is that, although the activities of the nurseries are the same, at present they fall into different sectors of MADERA's operations, the forestry and agricultural sectors, both of which set up nurseries. This could hamper coordination between the nurseries. This is a question of MADERA's internal organization and is not surprising in view of the rapid expansion of the program. It is only a temporary situation and can easily be resolved. 


\section{I PRODUCTION CONDITIONS}

\section{A - Limitations due to nursery size}

The size of the nurseries poses two problems:

- The need for plants is growing rapidly (but is difficult to quantify) as refugees return and agricultural activities are restarted. Fruit tree plants are very cheap and forest plants are practically free which makes them very attractive to farmers. The size of the nurseries will however restrict their ability to rapidly meet demand. At the moment, because the nurseries are not producing to their full capacity, this is not a limiting factor, but it could become one, at least for the smaller nurseries.

- In the longer term, if MADERA decides to withdraw from the project, in suitable cases production and distribution could be placed in private hands. One of the conditions for this would be that the number of trees produced, and therefore the land available, be sufficient to produce a reasonable profit. Therefore, the area should be capable of providing full employment for its staff (if the workforce is not a family one ).

One should bear these points in mind when the time comes to expand the nurseries or if new ones are established. However, the later is unlikely to occur except in areas which have no nursery nearby (such as the Parun valley which would be suitable for apple trees).

\section{B - Problems with expansion}

In the case of nurseries on open land, it seems easy to expand onto nearby fields. Nevertheless, MADERA should be careful in cases where they presently use private land free of charge, as is the case in Gulsalak and Kamdesh. If there is no alternative other than to rent land, one should be careful to maintain good relations with the present owner. The problem of expansion should be discussed with him and his suggestions solicited, unless it is decided to relocate the nursery altogether.

Asmar and Nawre nurseries are surrounded by walls. If necessary, additional fields could be rented, probably separate from the present nurseries.

Finally, the Bagh salar nursery is bordered by a road, a path and a canal and can only be expanded on a different site. One site has been suggested by the local authorities but it does not seem very suitable. 


\section{c - Condition of the land}

Asmar, Bagh Salar and Nawre nurseries face particular difficulties due to the fact that they are situated on land whose former function affects its present use.

Asmar was an officers' residence and has numerous adult trees which are a great inconvenience.

Bagh Salar was a state nursery from 1973 onwards and poses many problems such as the pathes, which are in poor condition but have already been improved by temporary workers. There are still too many adult trees, often too close together, narrow hedges and unstable fences.

Nawre was the garden of a schoolmaster's house. Its walls have been restored by MADERA, but the area is still cluttered with large old trees.

These nurseries have also suffered more severe war damage than other cultivated land. Nevertheless, they could be restored if the hiring of temporary staff was permitted.

\section{D - Availability of water}

Throughout the year, no nursery lacks water for watering. Nevertheless, two managers reported problems with their water supply.

At Bagh Salar the canal serving the nursery stops flowing periodically, due to damage to its intake on the River Pesh. The nursery's reservoir contains enough water to last until the canal is repaired but the upper terraces can only be watered by hand. It is therefore recommended that these terraces be planted with trees which require less water and that the supply of water from the canal be improved.

At Want constructing a small reservoir, as the manager suggests, would save the laborers time and effort.

$$
\text { E - Tools }
$$

The agricultural equipment used in the nurseries is, on the whole, the same as that used by local farmers. It is adapted to traditional tasks and is not always appropriate for the specific techniques used in the nurseries; e.g. weeding, levelling the soil, raking, sowing in rows, pruning, etc. Alain de Bures has suggested that the technicians in Nawre make a hoe modelled on a traditional tool used to de-bark trees, as its blade is the required shape.

Other tools have to be adapted, perfected, introduced or transferred from one area to another (e.g. a mattock used in Darra-e-Nur seems to produce good results). 
IV - STAFFING AND EXTENT OF ACTIVITIES

A - Size

The total personnel of the nurseries, management and laborers, is 20 for a total area of $36,350 \mathrm{~m} 2$. The staff are unequally distributed between the nurseries, ranging from 1 (at Gulsalak) to 4 (Asmar and Bagh Salar) while the size of the nurseries varies by a ratio of 1 (Kamdesh where plans for expansion should be implemented soon) to 20 (Bagh Salar).

\section{B - Management}

On the whole, the managers appointed by MADERA seem interested in their work, have an understanding of their environment and are enthusiastic and effective at disseminating their knowledge. Some lack technical skills, particularly grafting. Training courses organized by the FAO should fill this gap. All have much to learn regarding the organization of production and exploiting the potential of their nurseries. Management training is a must in the near future.

They must make greater efforts, particularly in the following areas:

- Keeping files, inventories, a diary of work and observations and distribution lists. Detailed lists of who has received plants enables managers to give preference to those who have not received plants previously, to follow- up different specles and to obtain grafts and cuttings. Printed forms could be provided for the managers.

- Report writing.

- The use of funds received from sales. These should not be used by anyone but should be sent in their entirety to MADERA's accounting department as soon as possible.

- Maintenance of the nurseries which are MADERA's shop window, particularly for local farmers.

- The careful separation of plots of different varleties to avoid mixing (labelling is a must). The names of each variety should be known and told to the buyers.

- The transportation of plants, cuttings or grafts which must be carefully labelled, protected against dehydration and transported and stored or used as quickly as possible.

- The supervision of the diligence and competence of their staff. All non-justifiable absences should be reported to the program. manager and the MADERA personnel chief. Managers should not forget that they must provide an example for their staff. 


\section{C - Laborers}

In certain cases, the junior staff recommended to MADERA do not give complete satisfaction and some lack competence or diligence which would justify sanctions or dismissal. However, the managers do not always have authority over staff who enjoy powerful outside influences. This explains, at least in part, why some managers demand more staff although the usual standards have already been exceeded.

\section{D - Land worked}

The area worked by one laborer varies between nurseries but is in general far below accepted norms (see chapter XI). The laborers still need to improve their skills and organize themselves better. Additionally, specific problems such as the presence of perennial weeds necessitating frequent weeding (not to mention the renovation required by some nurseries, as mentioned above) exist in some nurseries.

In addition, the management (i.e. the manager and to some extent the foreman, if there is one) are not always able to participate themselves in the work of the nursery, as their time is taken up with paper work, following up trees planted by farmers, coordination with other MADERA technicians and missions to Peshawar.

This may explain why the average area worked by each laborer is so low, but does not explain the differences between nurseries. MADERA should move step by step towards the standard norms.

In the near future, if the area under cultivation in a nursery is to be increased the recruitment of new laborers should be at a ratio of one man to 2 to 2.5 jeribs $(4,000 / 5,000 \mathrm{~m} 2)$.

\section{E - Organizational aspects}

At present, most work necessitating a large workforce is carried out by temporary personnel. This is acceptable as long as it is limited to specific tasks such as grafting or filling bags. At Bagh Salar one of the tractors from MADERA's agricultural center at Chawki could be used to prepare two jeribs of fallow land. At Qarghay and Nawre, one manager supervises the two nurseries. He wastes time traveling between the two and is unable to supervise either properly. A second manager should therefore be employed, so each nursery has its own. The number of laborers at each nursery should then be reduced unless expansion is foreseen. At Gulsalak the manager is the only employee and cannot leave the nursery unsupervised and unwatered while travelling in the villages or on a mission to Peshawar. He should be able to request one of three MADERA forestry agents employed in the area to stand in for him.

At Want the manager also wishes to be replaced whilst on mission, and, as in Gulsalak, could call on one of the forestry agents from the nearby villages. 


\section{V - POINTS CONCERNING FRUIT PLANT PRODUCTION}

As we shall see later, there are few difficulties with the production of forest plants at MADERA's nurseries (see chapters VI and VII). However, fruit tree production, which is often more complicated, does pose problems.

\section{A - Different types of fruit plants}

The plants distributed by the nurseries can be divided into three categories :

1 - Plants propagated from seeds

Walnut, loquat and guava tree, etc.

The seedlings of these species retain to a satisfactory degree the characteristics of the mother plant from which the seeds were taken. They can be further improved by grafting and if this is not done it is mainly because good varieties are not available for grafting.

\section{2 - Plants propagated from cuttings}

Quince, fig and pomegranate tree, vine.

This multiplication method is very important as it retains the genetic heritage of the mother plant. Unfortunately, it does not work with all species.

3 - Grafted plants

Grafting is mainly carried out on species whose seedlings produce heterogenous plants, notably where fruit quality is an issue and propagation from cuttings is not possible. Apricot, almond, orange, peach, apple, plum and mulberry trees are the most common species multiplied in this way. On rootstock of the same or a closely related species, often grown from seed, which does not fruit well (but has been selected for other qualities such as compatibility with the graft, suitability to soil conditions, resistance to certain diseases, early fruiting, etc), is grafted, by different methods adapted to the species or the season, a fragment including at least one bud from a good quality plant which one wishes to multiply. The new plant will therefore have the roots and a part of the trunk of the graft recipient, while the remainder will be the graft. This operation demands a knowledge of the specific techniques and takes time.

\section{B - Period of growth in the nurseries}

The diagram in table 2 gives a timeframe for the different operations necessary for the production of the 3 categories of fruit tree plant.

Those propagated from seeds or cuttings are ready after about one year. 
Grafted plants need 2 or more years before they are ready. Under the conditions in the areas where the nurseries are situated, a sowing during the cooler season (preferably at the onset of winter) of a suitable roostock variety of a species such as apricot, almond, peach or plum tree, will produce a subject strong enough (pencil size) to be grafted from the month of July of the first year. The grafted bud survives the winter in a state of hibernation and develops the following spring (of the second year). The plant will not be available for distribution until it has spent a further complete growing season at the nursery. It will be ready the following autumn and distributed in accordance with local habits between the start of February and the beginning of April (of the third year).

The practices of the nurserymen (grafting in the summer) and those of the farmers (planting at the end of winter) prolong the duration of plant production. We will see later (chapter $X$ ), that it is possible, by modifying these practices, to reduce the production cycle and thereby increase the productivity of the nurseries.

\section{C - Production potential}

As far as fruit plant production is concerned, the following norms are accepted:

- Space between cultivated rows: $90 \mathrm{~cm}$

- Space between plants in a row: $15 \mathrm{~cm}$

- Maximum number of plants on a plot of one "usable" jerib (1)

: 12,600 plants

This is a theoretical maximum number. The number of plants which can actually be produced should take into account the length of a cycle and risks to production. Losses, under the conditions under which MADERA currently operates, are estimated at one third of total production. The following averages are therefore suggested:

- Trees from seeds and cuttings: 8,400 plants/jerib/year

- Grafted trees distributed in the autumn after two years in a nursery:

$$
\text { 4,200 plants/jerib/year }
$$

- Grafted trees distributed at the end of winter after 2 years and 4 months in a nursery, taking into account the fact that the land is not available for any other cultivation for 3 years (land which is available from mid-February can only be used for fruit tree cuttings (see table 2) which need only a small space, unless poplars are also produced):

\section{2,800 plants/jerib/year}

(1): "usable" surface: cultivated plots, inclusive of 208 of small paths and irrigation channels. 1 usable jerib $=1,800 \mathrm{~m} 2$ of cultivable land. 
VI - NUMBERS OF PLANTS PRODUCED

Two sets of data are used to assess the number of plants currently produced in MADERA's nurseries and to what extent this has increased; the number distributed by the nurseries at the end of the winter of 1992 and the number available for distribution at the beginning of 1993 .

\section{A - 1992 distribution}

Of the 8 existing nurseries, in 1992 five distributed plants produced in situ: Asmar, Bagh Salar, Darra-e-Nur, Nawre and Want. This was the first distribution since they were established or taken over by MADERA. The newly established nurseries, Gulsalak, Kamdesh and Qarghay, had not produced any plants for distribution.

Not all the managers were able to provide distribution statistics. Those who did sometimes omitted such information as the names of the beneficiaries or their villages, and mistakes seem to occur in their lists, as the figures recorded do not tally with the numbers seen. Therefore the figures shown in tables 3 and 4 should only be considered as approximate. The following conclusions can, however, be drawn:

- 8 forestry species have been distributed, 17,500 plants in total. Most are of three species: deltoid poplar (Populus deltoides), black poplar (P. nigra) and Leucaena (L. leucocephala). The Asmar nursery distributed the most.

- Slightly more than 4,600 fruit plants were distributed of 10 species, of which peach trees, vines and apple trees made up more than half. Asmar and Bagh salar distributed $3 / 4$ of the trees.

A more detailed data analysis was possible at Bagh Salar. It shows that 151 people from 28 villages received plants from the nursery (an average of 5 to 6 people per village). Of these, 132 (70\%) received fruit trees and 55 (30\%) forest trees (some farmers received both).

The numbers distributed seem very low, particularly when compared with the number of villages covered. Table 5 shows the average number of both fruit and forest plants which each village near to a nursery should have received if the plants had been divided between them in equal shares. This is purely theoretical, but nevertheless shows that only Asmar, Bagh salar and Darra-e-Nur nurseries have distributed significant numbers of plants. 


\section{B - Expected 1993 distribution}

The number of plants which each nursery expects to distribute in early 1993 are shown in table 6 .

The number of forest plants to be distributed should be multiplied approximately by a factor of 4 and therefore increase from 17,700 plants to more than 70,900 plants (in all nurseries). This figure excludes both small village nurseries which produce a few hundred plants each and possible losses. Production is concentrated mainly in 4 nurseries; Bagh Salar, in particular, Want, Asmar and Darra-eNur.

On the other hand, the number of fruit trees to be distributed will increase more modestly, from 4,657 plants in 1992 to 6,630 in 1993, which is nevertheless an increase of $42.5 \%$. However, the number of fruit plants available will decrease at Asmar, Bagh Salar and Want (where no trees will be available in 1993).

This worrying situation is unfortunately confirmed if one looks at production from a qualitative point of view. 


\section{VII - QUALITATIVE ASPECTS}

The quality of the plants depends on two basic conditions:

- That they are propagated from good quality plants,

- and that they are raised during a period of good weather and under favorable conditions, which allow them to reach their full potential.

It is essential that they be planted in areas where the climate and soil meet their needs or preferences.

\section{A - Forest tree plants}

Although the plants produced in MADERA's nurseries appear to meet the first condition, the second does not seem to be achieved. For example, in the case of cedar cultivation at want:

- the bags are too small for the plants to develop properly,

- the soil mixture seems poorly suited to their needs,

- not enough organic manure is used,

- they are not always properly taken care of (in terms of shade, watering, etc),

- the species is being grown in an unfavorable climatic zone.

The cultivation of poplars on open ground as is practiced in MADERA's nurseries is not always in line with standard norms, especially in respect to spacing, which is too dense, but it still seems to produce satisfactory results. The needs of each species and the areas where they grow best should be better understood. This is true of most species of both fruit and forest trees.

\section{B - Fruit tree plants}

It is even more important that fruit trees be of good quality as they produce food and contribute to the family economy. One would expect farmers to be prepared to give more care to such trees to ensure better results.

Plants produced in MADERA nurseries propagated from seeds, such as loquat and walnut trees, vary little in terms of quality. This mode of multiplication is therefore acceptable, as long as the seeds are carefully selected. But when selected varieties become available grafting should be used, at least for walnut trees. 
Plants propagated from cuttings are the least problematic; this multiplication method retains the genetic heritage, $1 . e$. the characteristics, of the mother plant, and it has other obvious advantages. The 3 species currently multiplied in this way in MADERA's nurseries, fig and pomegranate trees, and vines, are traditionally cultivated in Afghanistan, and many more varieties could be investigated.

Grafted plants faithfully reproduce the characteristics of the tree from which the graft was taken. In view of the technical competence, care and time necessary to produce them and the needs and expectations of the farmers, they must be of perfect quality. MADERA's nurseries usually use grafts from selected varieties (often provided by the FAO).

According to current practice in Afghanistan, plants are distributed after 2 years and 2 to 4 months for a grafted plant and 1 year and 6 to 8 months for the graft only. On this basis, only the Darra-e-Nur nursery, set up in March 1990, should have been able to offer grafted plants in March 1992, if rootstock seedlings were propagated in the first weeks after it was set up.

Want, Asmar and Bagh Salar nurseries, which were set up or taken over by MADERA between December 1990 and April 1991, should not have grafted plants available for distribution until February or March 1993 (unless old grafted plants remained at Asmar and Bagh Salar). However, they distributed some in 1992 as shown in table 4. They have therefore distributed their grafted plants one year too soon.

This has had two very damaging consequences:

- The plants provided to farmers were not of the expected quality. In most cases, the graft had not developed and it is doubtful if they will recover. Even if they do survive, the graft will be very fragile and liable to damage whenever it is handled; during digging up, transportation or planting.

- There are no grafted plants available for distribution in 1993, as shown in table 6 (and no provision has been made to make up this deficit by propagating fruit trees from seeds or cuttings).

At Asmar, in particular, as shown in table 4, rootstock (mostly apple tree) has deliberately been distributed ungrafted. This failing is naturally regrettable even if was caused by the farmers' impatience, as it can discredit MADERA. An attempt to rectify the situation has been made by undertaking a campaign to graft these trees on the farmers own property. This was organized at the beginning of the summer of 1992. It should be followed up by regular visits. 


\section{VIII - ORGANIZATIONAL ASPECTS}

One can calculate, on the basis of the number of plants distributed, the area of usable land which, under optimum conditions, would have been sufficient for the level of production foreseen. By comparing this with the total usable land in each nursery, a 'land utilization rate' is obtained, which can vary from 0 to 100\%, and which can be considered as a nursery's management score. Tables 7A and 7B show the data for cultivation during 1991 and 1992 .

The land utilization rate for a given year is based on production intended for distribution at the beginning of the following year. To this is added the number of plants produced in previous years of species which spend more than one year at the nursery. A standard figure is assumed for each species. In other words, a nursery may be fuller than the land utilization rate would suggest, if the number of plants spending more than one year in the nursery is actually higher than the figure assumed.

In terms of land utilization, it must be admitted that the performance of MADERA's nurseries is variable but in general it is low and getting lower. It dropped from an average of $15.3 \%$ in 1991 to an average of $9.7 \%$ in 1992, despite a clear increase in the number of trees produced (which resulted from the premature distribution of grafted plants). However, some nurseries have produced good results (Asmar for its distributed production in 1992 and Gulsalak for the distribution forecast for 1993) which should be consolidated by improving the skills and experience of the nursery personnel.

In the future, each nursery should be able to define it's production goals (see chapter XB) in order to be able to devise a strategy for meeting them. 


\section{IX - FINANCIAL ASPECTS}

A number of difficulties arise when examining MADERA's nurseries from a financial point of view, notably:

- the diversity of funding sources

- the lack of details concerning some expenditure.

To limit the possibility of uncertainty and errors, it seems sensible to analyze the nurseries financed by the FAO, Asmar, Bagh Salar, Kamdesh and Want, which have a specific budget for a period of one year, from November 1991 to November 1992, which more or less corresponds to one year of cultivation.

\section{A - Estimate of committed expenditure}

As the budget period is not yet complete, expenditure for the remaining period is estimated.

According to Mr. Ismaël, the manager of the forestry program, the expenditure incurred during the year should correspond to the total FAO budget, supplemented for some posts by funding from other sources.

- Personne1

- Equipment \& materials

- Various expenditure

Total FAO budget:

- Transport supplement

- Supplement for part of the salary of the forestry program manager

- Id. for Adviser forestry program

Total :
Rs 368,400
Rs 354,365
Rs 105,400
$--1828,165$

Rs 12,800

$\begin{array}{lr}\text { Rs } & 24,000 \\ \text { Rs } & 4,000\end{array}$

Rs 868,965

The total budget of Rs 868,965 includes some expenditure which is not directly related to nursery activities (e.g. the purchase of motorcycles and their running costs and maintenance) or have not contributed to 1992 production, but to the production be distributed in early 1993 (e.g apple tree rootstock); Rs 288,550 Rs have therefore been deducted from the total amount, which is reduced to Rs 580,415 .

The amounts allocated to the different budget heads have been divided between the 4 nurseries as fairly as possible, either according to number of staff (salaries), equally (some tools, transport costs, administration) or according to size. 
A distinction has been made between investment expenditure, which can be considered as written off over a 5 year period, and annual running costs.

\section{B - Cost price of plants}

Table 8 shows an estimate of the cost price of one plant.

For the four nurseries, expenditure related to 1992 production approached Rs 550,000. By dividing this amount by the total number of plants produced, a cost price of approximately Rs 8 to 9 per plant is obtained. However, fruit trees in general cost more to produce than forest plants and have therefore been sold at Rs 2 each, against Rs 0.5 each for a forest plant since the beginning of 1992. If this ratio of 4 to 1 is applied, the average cost price of one fruit plant is around Rs 30 and that of a forest plant Rs 7.5.

These prices are much higher than those charged by commercial nurseries in Pakistan where a grafted plant is sold at between Rs 10 and Rs 15 (moreover, none of the fruit tree plants produced in 1992 for distribution in 1993 were grafted).

The cost price varies widely between nurseries, the lowest being at Bagh Salar and Want. In the same way that the land utilization rate enables us to assess the nurseries from a technical point of view, the cost price enables us to evaluate them from a financial standpoint.

Such figures are not available for the other nurseries, but they are doubtless equally heterogenous and excessive and stricter management is necessary for all the nurseries. 


\section{X - GOALS FOR IMPROVEMENT}

The study of MADERA's nurseries, both from a technical and a financial point of view, reveals an unsatisfactory situation. To better answer farmers' needs, MADERA's nurseries should aim to increase the number and the quality of the plants on offer.

To improve quality, as seen above, carefully selected plant stock, adapted to local conditions and traditional practices must be used.

It is possible to increase the number of plants available to farmers by:

- limiting the length of time plants spend in the nurseries without endangering their quality and

- better organizing production with a view to the optimal use of land.

\section{A - Limiting the production cycle \\ 1 - Changes to the timing of distribution}

For both fruit and forest trees the dates of sowing and taking cuttings in the open air cannot be changed because of biological constraints.

One the other hand, distribution which is currently carried out for all species towards the end of winter or at the beginning of spring, depending on the site (earlier at low altitudes, later at higher altitudes) could be done at the end of the fall which is just as favorable for planting.

The land occupied by these plants would therefore be free in November or December instead of in February or April of the following year, gaining 3 to 5 months and enabling a new cycle of production to be started (or the land to be left fallow).

Any change to the timing of distribution and planting would certainly conflict with the habits of nurserymen and local farmers, who give two main replies when asked why they plant when they do:

- the period from November to January is a rest period for the farmers,

- in the fall water is scarcer than in spring and it may be difficult to water the new plants.

In any case, a price incentive would doubtless eventually overcome the farmers' resistance. At the beginning, the fall plantings will have to be followed up very closely. Distribution at the end of winter should not be halted entirely, giving the nursery managers greater flexibility in the organization of their activities. It would be preferable if the fall distribution freed the whole nursery for new seedlings (see the diagram in table 2), so cuttings could be taken after the winter distribution. 


\section{2 - Possible changes to the grafting period}

As with distribution and planting, grafting could also be done at a different time of year. But here too habits are deeply rooted; inverted $T$ budding is always done in August or September. There are certainly good reasons for this; at this time of year the success rate is nearly 1008 by grafting rootstock produced the same year which have reached the correct diameter. Because this method works so well and is recommended by the FAO, many nursery- men, especially MADERA's, do not consider other options, admittedly less certain of success, but which facilitate production planning and allow them, if not to reduce the production cycle, at least to prevent it from becoming longer.

The grafting of trees can be done at the end of winter or at the beginning of spring using the chip-budding technique. This method is slightly less successful $(70 \%)$ and is more time-consuming than the inverted $T$ ( 150 grafts can be cut by an experienced grafter compared with 500) but it allows re-grafting on plants on which the fall grafting was unsuccessful. If this technique is not used these plants will only be grafted the following summer, at the same time as that year's rootstock and they will lose one year of the normal production cycle. Inverted $T$ budding can be carried out in March/April for cherry and apple trees and in May/June for apricot, almond, peach and plum trees. MADERA's nurseries would benefit if these techniques were introduced immediately to complement current practices.

\section{B - The organization of production}

Each year a production plan must be prepared for each nursery based on these needs, which are estimated from the demands, satisfied and unsatisfied, made of previous campaigns and the current campaign, and the nurserymen's knowledge of the needs and limitations of different species. A plan should be prepared by each nursery manager and discussed with the program manager during the summer so that all selected plant stock required (seeds, apple tree rootstock, grafts and grafted plants ready for distribution), by the nurseries is known and can be communicated from September to MADERA's partner organizations, especially the FAO, so they can supply them within the required time.

Table 9 is a simplified production plan for a fictitious nursery, of which the usable area, $7,000 \mathrm{~m} 2$, is similar to that of Asmar. The number of plants to be produced is optimal for the area assigned to each species. It is nevertheless a perfectly achievable goal.

To draw up such a plan, firstly the proportion of the nursery, in terms of number of plants and surface area, to be devoted to forest and fruit production respectively must be decided. 
When forest production is considered, it must be borne in mind that poplars need a lot of land compared with other species, despite the density of planting.

As for fruit tree production, the maximum number of grafted plants of different species to be distributed at the end of the fall of the current year or at the end of the following winter (year 1) should already have been determined, as should those for the following year (year 2). The amount of land they require is also known, so the remaining available land (and the maximum number of plants possible) can be calculated. This should be used to produce rootstock to ensure the continuity of grafted plant production and to raise plants which cannot be grafted from seeds and cuttings.

If the number of grafted plants available for the next distribution (year 1) seems inadequate, selected plants can then be bought for immediate distribution. If the same problem arises the following year (year 2) plants propagated from seeds and cuttings should be produced at the nursery at the end of the current year and the beginning of the following year (while still purchasing plants for immediate distribution).

For apple trees in particular, the approximate number of specimens which could be produced by layering and the amount of space to set aside for their production needs to be evaluated without undue optimism as to possible numbers.

Once the plan has been prepared, the geographical organization of production within the nursery (distribution of cultivation) will have to be plotted on a map, being careful to ensure, for health reasons, that the same plot is not used for the same species twice in succession and, if possible, that two species of stone fruit are not grown in succession on the same plot.

A task timetable should be drawn up, describing the activities of the permanent staff and the possible use of temporary personnel.

Table 9 shows that on $7,000 \mathrm{~m} 2$ of useful land ( 3.5 jeribs), whereas Asmar nursery will probably produce 7,580 plants (produced in 1992, distributed in 1993), one should, in theory, produce annually (baring accidents):

- 64,200 forest plants

- 6 to 9,000 grafted fruit plants

- 5,420 non-grafted fruit plants

A total of 75,000 to 78,000 plants (more than 10 plants per usable m2). 
Nursery managers need to take steps to improve the use of their workforce. In addition, they should introduce prices more closely related to the actual costs of production.

\section{A - Expenditure reduction}

The largest budget head in the 4 nurseries funded by the FAO, is salaries which represent Rs 368,400 of a total budget of Rs 828,165 (see chapter IX).

It is therefore on personnel costs that MADERA can make the most substantial savings.

The activities of a nursery require one laborer per 4 to $6,000 \mathrm{~m} 2$ (2 to 3 jeribs). A norm of one worker per $5000 \mathrm{~m} 2$ (2.5 jeribs) is current in private nurseries.

However, the management of MADERA's nurseries (the manager and to a certain extent the foreman) are expected to carry out duties unrelated to production (see chapter IV). The manager therefore only participates in the work of the nursery for half his time. Table 10 shows the amount of land worked per laborer at MADERA's nurseries; from $465 \mathrm{~m} 2$ at Kamdesh (soon to be expanded), to 4,665 m2 at Bagh Salar, a variation by a factor of 10 . The average is around 2,425 $\mathrm{m} 2$, approximately half the accepted norm. Expenditure on laborers can therefore be reduced by half.

This can be done in two ways; either by reducing the number of staff or by increasing the amount of land.

The minimum workforce possible is one manager and one laborer (a workforce of 1.5 men), the minimum nursery size should therefore be $6,000 \mathrm{~m} 2$ ( 3 jeribs). The question of the future of smaller nurseries must be addressed as a priority, but any changes could only be implemented in stages.

\section{B - Introduction of realistic prices}

The prices charged by MADERA's nurseries for the 1992 distribution were, in general, as follows:

- Rs 0.5 per forest tree plant

- Rs 2 per fruit tree plant.

These extremely low prices were set at this level to encourage as many people as possible to buy plants. However, in order to make the nurseries profitable, prices which reflect actual production costs must be introduced.

No more than one rupee per plant can be charged for forest plants or no-one will buy them. A distinction should be made between grafted 
and ungrafted fruit tree plants, as the latter are ready for distribution twice as quickly and produce twice as many plants a year on the same amount of land.

From one usable jerib one can produce each year:

$-4,200$ grafted fruit plants

- 8,400 fruit plants propagated from seeds or cuttings.

To be profitable, the income from one jerib of grafted fruit plants, which are more expensive to produce, must therefore be higher than that from ungrafted plants or there is no point in producing them.

In view of this, the following prices are suggested:

- Rs 1 per forest plant, giving an income of Rs 285,700/ usable jerib/year;

- Rs 3 per ungrafted fruit plant giving an income of Rs $25,200 /$ usable jerib/year;

Rs 10 per grafted fruit plant, giving an income of Rs $42,000 /$ usable jerib/year.

These prices could be achieved in stages over 2 to 3 years. They should be reviewed in line with any changes in the rupee or the afghani exchange rates.

\section{C - Expected results}

Increasing the level of production (see chapter $X$ ) and reducing expenditure should enable the nurseries to become profitable. Table 11 shows the financial result of optimum land use, including limiting the production cycle for grafted plants to 2 years. Table $11 \mathrm{~A}$ applies the land use and production hypothesis from table 1 to Asmar nursery's 1992 production costs as shown in table 8 . A nursery of 7,000 usable $\mathrm{m} 2$ can be looked after by one manager (the owner in the private sector) and one laborer, a workforce of 1.5 men or 1 man per 4,670 m2. By applying this to Asmar's present situation, one would save:

- 1 Foreman at Rs 2,750/month or Rs 33,000/year

- 1 Laborer at Rs 1,500/month or RS 18,000/year

Making a total annual saving of Rs 51,000 reducing the annual budget from Rs 212,445 to Rs 161,445. The production cost of one forest plant can therefore be reduced to Rs 1.35 and that of one fruit plant to Rs 5.3 (if the cost price of a fruit tree plant is taken as 4 times that of a forest plant).

Table 11B shows that by implementing the proposed price increases, a nursery of 7,000 usable m2 could produce a surplus of Rs 9,000 per year under ideal conditions. This sum should not be considered as profit but should be reinvested, for example, to purchase selected apple tree rootstock (the extra production cost of grafted apple trees could later be recovered on the sale price). 
XII - PRIVATIZATION OBJECTIVE

\section{A - Hypothes is}

The original aim of MADERA's nurseries was essentially technical; to produce the maximum number of plants in order to satisfy a large demand.

However, at some point MADERA will have to withdraw from the nurseries and the consequences of this will be less damaging for the production of plants and for the farmers who will plant them if the withdrawal has been well thought out and prepared for in advance.

The take over of the nurseries by the Afghan authorities is an attractive solution, but it assumes changes in the country which unfortunately seem unlikely to occur. It assumes that the Afghan authorities will be interested in taking over the system set up by MADERA and that they will have the means to do so. It therefore seems sensible for MADERA to seek other solutions to the future of the nurseries and if possible for all their activities.

The least problematic solution would be to hand the nurseries over not to a theoretical administration, but directly to the population. This philosophy of withdrawal in favor of the population should force local inhabitants to abandon the illusion that they can always rely on providential assistance. It might also give MADERA's Afghan staff, who already see themselves as bureaucrats, a more realistic understanding of their position.

If MADERA adopts this philosophy, it is important that all the managers should be convinced of it's validity before attempting to explain it to the rest of MADERA's staff and the local population. The goal must be essentially economic, particularly for the nurseries, which must become profitable in order to attract private individuals. This would be the best way for MADERA to withdraw.

Privatization will inevitably take a long time and will meet with many obstacle. The time available to MADERA to prepare for this step is impossible to predict but it must be embarked upon as a matter of urgency.

\section{B - Preparatory activities}

MADERA's nurseries should gradually adopt private management practices. Some possible ways of doing so are given below.

As seen above (chapter XIB), forest plants grown in bags are the most profitable for the amount of land used. Nevertheless this production is limited by demand and should anly be developed carefully. 
Nursery managers would be advised to increase the amount of land dedicated to the production of non-grafted fruit plants. The distance between rows can be reduced from $0.90 \mathrm{~m}$ to $0.60 \mathrm{~m}$ for seeds and cuttings. This would enable 18,600 plants/usable jerib to be grown, an annual production of 12,400 plants/usable jerib, (instead of 8,400$)$, assuming the loss of one third of production. At Rs 3 per plant, the expected income would increase from Rs 25,200 to Rs $37,200 /$ usable jerib/year, an extra profit of Rs 12,000 .

The production of poplars, on the other hand, is not so attractive, as they need a lot of space and are not very profitable. One usable jerib will produce 8,400 plants, which at the price of Rs 1 per plant (it does not seem possible to charge more), represents an annual income of Rs 8,400 (to rent one jerib of land would cost about Rs 5,000 per year). The cultivation of poplars has therefore very little chance of surviving privatization. MADERA's nurseries could, in future, produce merely good quality trees which will provide cuttings which can be distributed without roots at a reduced price ( 5 to 10 cuttings for Rs 1). The farmers will then be taught how to take care of the cuttings.

Land should not remain fallow for long periods, even in nurseries which do not need renovation.

Carefully checking the condition of the plants and the sensible use of chemical treatments will limit mortality and reduce the percentage losses.

\section{C - Implementation \\ 1 - The takeover of the nurseries}

It should be possible for MADERA to transfer all the production and distribution activities of a nursery as a going concern to a private individual who will dedicate all his time to it and make a reasonable living from it. The recommended minimum size would be between 2 and 3 jeribs $(4,000$ to $6,000 \mathrm{~m} 2)$ which could be looked after by one man (with the possible assistance of one or two of his children). As seen above (chapter XIA), the smallest viable size for a MADERA nursery is one which can support a permanent work force of 1.5 men, at one man per 4 to $6,000 \mathrm{~m} 2$. This gives a minimum surface area of $6,000 \mathrm{~m} 2$ and a maximum (but optimum) of $9,000 \mathrm{~m} 2$. If a nursery taken over by a farmer has a surface area of 6 to 9,000 m2, he will not be able to take care of it alone and will either have to reduce the area under cultivation or employ extra help.

It would be better if the nurseries were taken over by the owner of the land, otherwise the farmer will have to spend Rs 10,000 to 15,000 of his annual income on rent (at Rs 5,000 per jerib) which would reduce its chances of becoming profitable. Even if he owns the land, he will lose the income from cereal production which yields shorter term results. In either case, he will need sufficient capital to enable him to meet production costs and to wait for 10 
months to one year (the first distribution) before receiving any income.

The prospective nurseryman must have the necessary technical and management skills and be very well-motivated. He would be supervised and supported by MADERA.

This is demanding a lot from one man but it should be possible to find someone, a nursery employee or a particularly able farmer, who is willing and able to take over a nursery with MADERA's support. The task of the present nursery managers is to find and select candidates and prepare them for the task ahead.

\section{2 - Production of plants at home}

This solution would entail encouraging farmers with experience of grafting ("Paiwan Wala") or who have received training at a MADERA nursery to diversify their income by producing small numbers of trees ( 10 to 20 grafted plants a year to start with). Each MADERA nursery could provide dozens of farmers with apple tree rootstock (2 or 3 to be multiplied by layering) and at the appropriate time with the buds, or alternatively with polyethylene bags and forest tree seeds.

The nursery managers would supervise the different stages of production at the farmers' property. The farmers would either keep all or some of the trees and plant them in their own fields or sell them directly to other farmers or resell them to MADERA. Care should be taken to ensure that MADERA does not compete with these small producers.

In this way farmers would be able to retain a diversified income and familiarize themselves with production tasks without having to worry about distribution. This would involve less risks than the other suggested solutions but would be time-consuming for the nursery managers and foremen. It may lead to the discovery of farmers willing to take over an existing nursery or to start a new one, whose abilities could be fairly judged. It therefore seems preferable to the simple transfer of a nursery from MADERA to a private individual.

All future activities in MADERA's nurseries should be viewed as part of the transition to privatization. 


\section{XIII - RECOMMENDATIONS}

A - General recommendations

1 - For a new horticultural sector

- Eor the present all MADERA's nurseries should concentrate on one sector and forestry would seem the most appropriate.

- The early establishment of a horticultural sector at MADERA seems essential. The new sector would cover fruit tree and vegetable productions in different provinces.

- The sector would be under the management of an expatriate assisted by an Afghan counterpart. Their roles would be as follows :

- To provide technical guidance and develop MADERA's activities in the horticultural sector to give it a real impact (guaranteeing the quality of production and ensuring the supply of selected plant stock).

- To stimulate the necessary organization and management activities to promote the profitability of the nurseries and prepare for the privatization of production and distribution.

- To encourage nursery managers to work harder and meet their training needs.

- To maintain close collaboration with other programs, especially forestry and agriculture.

\section{2 - Quality Control}

- MADERA nurseries must make absolutely certain that they only produce and distribute trees of the best quality (species or selected varieties, free of disease), ecologically adapted to their environment. The behavior of different species should be tested before any major distribution. Grafted plants where the graft has not been allowed to grow in the nursery must not be distributed (this is particularly important in the case of rootstock, except in the case of experiments in privatization).

- Nurseries will multiply the best varieties, obtained from the best sources. They will represent (on their own or private land), carefully indexed collections of fruit trees (at least 3 of each variety) which will be closely monitored and will be used as mother plants from which grafts or cuttings can be taken. MADERA should experiment with a wide range of varieties even if this range is reduced by subsequent privatization. 
- Priority should be given to the follow-up of plantings on farmers" own land, not only to spread technical knowledge, but also to study the behavior of different varieties and species under different ecological conditions.

- A simplified weather station, including a maximum-minimum thermometer and a direct-reading rain gauge should be installed in each nursery and in villages where MADERA is established and the ecological conditions are different but representative. At each site, someone will be trained to measure temperature and precipitation and will be responsible for regular data collection.

\section{3 - Efficiency and profitability}

- The duration of grafted plant production will be, as far as possible, reduced to 2 years by distributing in the fall.

- At each nursery where this required, the number of staff should be brought in line with the area worked, on the basis of 1 laborer per 2 to 2.5 jeribs (4 to $5,000 \mathrm{~m} 2$ ). This ratio could be improved later as long as quality does not suffer.

- Each nursery must define its production goals from September 1992 with a view to optimizing land use. Each year nursery managers should draw up a production plan, a plan of the distribution of cultivation and a work timetable.

- An order will be placed with the FAO in september 1992 to meet the nurseries needs for rootstock, cuttings and grafts for the following 6 months, with a request for grafted plants to be distributed in 1993 (in the absence of plants produced by the nurseries). Any plant stock for the 4 nurseries not financed by the FAO should be paid for from another budget.

- Sale prices corresponding to the true costs of production must be introduced in stages.

\section{4 - Privatization}

- In the light of MADERA's future withdrawal, the privatization of the production, and if possible the distribution of the plants, should be promoted. MADERA will remain responsible for dissemination and popularization for as long as they are active in the areas concerned.

- MADERA's nurseries will try to improve the skills of traditional grafters by teaching them different grafting methods, how to take cuttings, pruning, etc. In areas where there are no traditional grafters or not enough, MADERA should consider training new ones, designated by the shura. 
- Nurseries could seek the help of local people at grafting time. They should encourage the most motivated who would like to start their own nursery in the future, giving priority to developing management skilis.

- At each nursery at or near a MADERA center the necessary arrangements should be made for farmers on courses and for MADERA staff on mission.

\section{5 - Distribution and popularization}

- Although at present, most problems occur in the area of production and the fields of distribution and popularization give satisfactory results, both areas could still benefit from better management.

- Fixed quotas are necessary for species of which only small numbers are available for distribution. This will enable more people to receive plants and more information to be gathered on the plants' behavior under different conditions. It should also prevent farmers from reselling them at a profit.

- Popularization should not be limited to technical advice on choice of species and their care. Advice should also be given on fruit preservation (the drying of apricots, mulberries, figs and grapes) and marketing.

\section{6 - Agroforestry}

- It would be interesting to experiment with adapted forest and fruit tree species on sites at the base of non-irrigated slopes, which are presently unproductive. MADERA could plant and supervise them with the agreement of the owners or the Shuras, undertaking all or part of the costs of watering (necessary for the first 2 years), caretaking and the supply of plants.

- Grafts of wild trees, with the help of improved species and varieties, could also be tried.

\section{7 - Integration and collaboration}

- Nurseries must improve their collaboration in terms of technical knowledge and plant stock. For example, Asmar nursery (forestry program), whose manager participated in the August 1992 grafting campaign and has taught staff from other nurseries, could provide other nurseries (agricultural program) with apple tree rootstock (given by the FAO) as foreseen by $M$. 
- It would be useful to hold one or two meetings of nursery and program managers each year to discuss topics such as; production, distribution, popularization, privatization, etc. The meetings could include papers prepared by the participants and the exchange of experiences and ideas. A report would be prepared after each meeting.

- Collaboration between the nurseries and the agricultural centers should be strengthened, for example in the following areas :

- Pest control; the provision of remedies and relevant information. The agricultural pest control sector hould also work with the forestry sector. As with veterinary products, agreement could be made with traders in towns such as Shaga Serai or Mehtarlam to supply pest control products to farmers possessing a 'prescription' from an agricultural center or nursery.

- Distribution of vegetable seeds; the vegetable seed budgets of the EEC's 18 month program and the FAO program could be combined to the benefit of both the agricultural and the forestry sectors, which would have to coordinate their activities. Vegetable seeds are available at the Sariab center in quetta (Agriculture Research Center).

- The popularization and follow-up of agricultural and horticultural activities;joint action could be taken in the villages (at least in specific areas).

- To involve MADERA's geographical managers in the nurseries' activities, the production and distribution programs at least should be explained to them.

- Collaboration should be sought or improved with the FAO and other NGOs working in the fields of nurseries and vegetable gardens. Competition between organizations should be avoided as the distribution of free plants and seedlings could undermine efforts at privatization.

B - Specific recommendations

Expansion problems have been covered in chapters XIA and XIIIA.

1 - Affecting several nurseries

Bagh Salar, Nawre, Qarghay and Want nurseries:

These nurseries in particular have a serious problem with a perennial weed (Cyperus conglomeratus) which is very difficult to eliminate by hand and necessitates frequent weeding. 
The following could be tried on small aréas at first :

- Spraying with 2-4D avoiding the leaves.

- If this does not work, other products could be tried, such as aminothiazole + ammonium thiocyanate or fluazifop-p Butyl if
they are available in Pakistan.

- Plastic mulching could also be used, at least on those plants most likely to suffer (i.e. seedlings).

Asmar, Bagh Salar and Nawre nurseries:

These three nurseries are seriously handicapped by their former use and the neglect they have suffered during the war. They need to be gradually restored with the consent of the owner or the local authorities, by using temporary staff. The budget for these staff should preferably be for all three nurseries and be managed jointly by the agriculture and forestry programs and should be used over 18 months to 2 years. It could be around 600 hours/jerib. The nursery managers should provide the program managers with a restoration plan and a timetable and justify their demands for laborers.

Gulsalak and Qarghay nurseries:

Wind breaks should be planted at these nurseries, at least on the most exposed sides. A bush called "Senjet" in Dari (Eleagnus sp.) and widely planted in Laghman could be used.

Nawre and Qarghay nurseries:

Both nurseries have very compact soil which should be lightened by adding river sand and manure, transport could be organized by the Qarghay center. A second nursery manager should be employed so each nursery has its own manager.

\section{2 - Affecting one nursery}

Bagh Salar nursery:

To solve the problem of sporadic interruptions to the supply of water from the canal it would be desirable to:

- Transfer multiplication plots from the top terraces to ones below the reservoir and keep the higher terraces for plants collection, etc).

- Look into the possibility of rehabilitating the water intake which no NGOs have worked on as yet, although whether it is included in any organization's program should be checked (DACAAR has worked elsewhere on the canal). It should be stressed that many farmers benefit from this canal. 
- The topographic conditions are suitable for siphon watering.

It would be useful if the nursery could sometimes have access to a small tractor from the Chawki (or the Petch) agricultural center. Mr Agha Sherim, the center manager, could give any necessary training.

Gulsalak nursery:

This nursery should be expanded on to nearby land or transferred to Kanday when the agricultural center is completed, unless another plot with the necessary attributes is rented. In view of the investment already made in the nursery and the proximity of the sawmill, the present plot should be kept and used for collections of plants or for research. The poor soil needs a lot of organic manure (which is difficult to find locally and to transport).

A forestry assistant from the area should be asked to replace Mr Samar Gol during his absences.

Want nursery:

A reservoir with a capacity of two cubic meters should be built to facilitate watering. The best place to put it in relation to soil level will have to be decided; if possible, it should be situated above all or part of the nursery, which could then be watered with a hose pipe (the usual method of watering could still be used when necessary).

As suggested by $M r$ Ismaël, a forestry assistant from a nearby village could work at the nursery sometimes, especially during the
manager's absence. 


\section{ANNEX I - NOTES ON SOME FRUIT TREE SPECIES}

ALMOND TREE: "Ferragnes", a very late-blooming variety, is the most suitable at altitude. "Ferrastar" and "Late Karghazi" are also useful. "Karghazi" is an excellent variety with a thin shell, which is suitable for altitudes of 1,000 to $1,200 \mathrm{~m}$ (e.g. Want). These varieties are grafted on bitter almond or hybrid almond-peach trees (GF 677 for example).

APPLE TREE: This species is in great demand. The following varieties can be planted:

- "Karja" is suitable for the lower valleys (around Shagasaraï, Darra-e-Nur, Jalalabad, Qarghay) as are "Kati" and "Gala"

-"Shin kulu" and "Tur Kulu" are suitable for higher altitudes (Kamdesh, Asmar, Want, Gulsalak) as is "Amri".

-"Spanten Spur", a late-blooming variety, is highly recommended for high altitude (Hazaradjat for example) as are those mentioned above.

Rootstock MM 106 gives excellent results (bears fruit after 2 to 3 years and is in full production after 4 to 5 years). This rootstock should be spaced between $5 \times 5 \mathrm{~m}$ and $6 \times 6$ m apart in orchards. Apple trees fruit better when cross-fertilized; plants of two different varieties should be planted next to one another and farmers should never be given one variety only.

APRICOT TREE: Two local late-blooming varieties are recommended for high altitudes; "Nari" and "Serdi". Another local variety, "Charmaghs", which blooms early is better at lower altitudes (between 1,000 and $1,200 \mathrm{~m}$ ). Grafting is carried out on apricot seedlings. Mercy Corps International (MCI), based in quetta (box 314, Tel: 40960, Fax: 43019) has devised a very interesting way to dry apricots. It organizes one week training courses in Quetta and Kandahar. Board and lodging are provided. Places are available for two of MADERA's staff and they can be contacted through the FAO.

CAPER TREE: Capparis spinosa, the species which produces capers, grows wild in Kunar and Laghman, but unfortunately the local population does not use the fruit. It can be propagated in bags under plastic film and planted on low-lying non-irrigated land in March taking care not to destroy the earth around the roots. Watering is useful during the first year, except in the rainy season and the plants have to be protected from cattle.

CHERRY TREE: The late-blooming variety "local black" is suitable in all zones. "Lambert" should also give good results. It is grafted onto P. mahaleb or P. mazzard. To encourage more flowers, it is better to plant different varieties of cherry tree next to each other. When distributing cherry trees remember to give two plants of different varieties. The promotion of bee-keeping will improve the pollination of fruit trees (and provide extra income from the sale 
of honey). MADERA should obtain different varieties from the FAO for the collections at Asmar, Want and Gulsalak (and eventually for the Hazaradjat) so their behavior can be evaluated.

FIG TREE: Good varieties of F. carica could be introduced.

HAZELNUT TREE: Like almonds, walnuts and pistachios the fruit of these species are protected by a shell and keep very well. They are suited to the climate in the high valleys. Mr J Braud, with good reason, recommended that they be, introduced.

JUJUBE TREE: Varieties producing better fruit could be grafted in the wild onto the wild species common in Nooristan.

KAKI TREE: A wild species, Diospyros lotus, which is an excellent rootstock for the fruit-producing species $D$. kaki is found in Nooristan and Darra-e-Nur among other areas. Cleft grafting can be done in February. It is possible to graft onto wild trees in order to produce grafted plants in the nurseries, starting with seedlings produced from seeds gathered in the wild.

MULBERRY TREE: MADERA's nurseries produce grafted mulberry trees. However, it is not worth continuing to do so unless better varieties can be found to compete with those produced by traditional grafters.

NECTARINE TREE: "Folewer Top" and "Stak Red Gold" can grow at high altitudes (up to at least $1,700 \mathrm{~m}$ ). They are grafted onto local peach trees.

OLIVE TREE: Olea Cuspidata, the native species, was successfully grafted with the cultivated species (0. Europaca) around Jalalabad. olives are not eaten in these areas. The wild variety could be multiplied for "dry" cultivation.

PEACH TREE: "Red Haven" and "Alberta" are recommended at high altitudes. They can be grafted onto peach, bitter almond or peachalmond hybrid trees.

PISTACHIO TREE: Different species have been observed in the wild, particularly around Want. Pistacia vera has also been found around Wama (Parun valley). P. atlantica grows in Afghanistan at altitudes of between 1,200 to $1,800 \mathrm{~m}$, with a rainfall of 250 to $400 \mathrm{~mm}$. This species grows to a considerable size. It is excellent rootstock for the fruitbearing variety (P. vera). Adult plants could be grafted in the wild and grafted plants produced in the nurseries. The species is diotic i.e. there are male and female trees. Adult trees are grafted in corona at the end of Winter and the beginning of Spring. The production of grafted plants requires the harvest of ripe seeds from wild trees. These seeds should be quickly sown in the nursery (in bags) as they will only germinate for a short time. Grafting is carried out in June or September when the rootstock is of a large enough diameter. They should be planted on non-irrigated land at the start of the rains (which are at their peak from March to May in the valleys). They should be watered periodically during the first two 
years and protected from cattle. They can also be planted on irrigated land which should produce a. better yield. The Sariab station in Quetta has good quality rootstock.

PLUM TREE: "Stanley" can be eaten fresh or dried, and is therefore very useful in isolated areas in winter (according to Mr A. Fitzherbert). "Blue Free" is an excellent table variety. Both varieties are late-blooming and are adapted to high altitudes. They are best grafted onto bitter almond trees (grown from seedlings). Two local varieties, "Santa Rosa" and "Herris Monarch", are very popular in the market and can be grafted onto apricot or bitter almond trees.

POMEGRANATE TREE: It is possible to introduce varieties which do well in other areas (especially Kandahar). These varieties could also be grafted onto local plants to improve their quality and to study any effect on their resistance to drought with a view to "dry" cultivation.

VINE: "Keshmesh" and "Shindo Khani" are seedless varieties which can be dried. "Aeta" and "Sahibie" are varieties with seeds. All four can be grown at high altitudes.

WALNUT TREE: The notes on the mulberry tree also apply to this species; the plants produced by MADERA are no better than traditional species. The FAO does not have any improved varieties in Pakistan. Maybe one can be found in an area where it was introduced by a foreign or international organization before the war. Trees worthy of being multiplied by grafting could maybe be found in the valleys. Unfortunately timber from this species is not particularly prized in Afghanistan.

Other species are worth trying, trying again or growing more widely, such as:

Citrus fruit trees: Lemon, tangerine, orange and grapefruit trees

Avocado tree (in lower valleys)

Chestnut tree (introductory trials have already been carried out at Mr J. Braud's suggestion)

Quince tree

Corossalier

Guava tree

Kiwi tree

Pear tree

Different types of apple tree, etc. 
ANNEX 2 - NOTES ON THE TRANSPORT OF PLANT STOCK

Plants, cuttings, grafts, etc often have to be transported to the nurseries.

Branches, which are liable to dehydrate, should be cut early in the morning. Branches of the same variety should be sorted by length, packed in small numbers, labelled (variety, origin, date) and wrapped in several layers of wet newspaper. These packages should be packed separately in thick plastic bags and hermetically sealed under vacuum. The bags should also be labelled and placed in an ice box and the ice replaced as often as is necessary. The journey and any delay before use must be kept as short as posible.

The bags should be taken out of the ice box (or the fridge to which they may have been transferred) and opened only as and when required.

They can be stored for longer periods in the freezer compartment of the fridge. 
ANNEX 3 : TABLES 


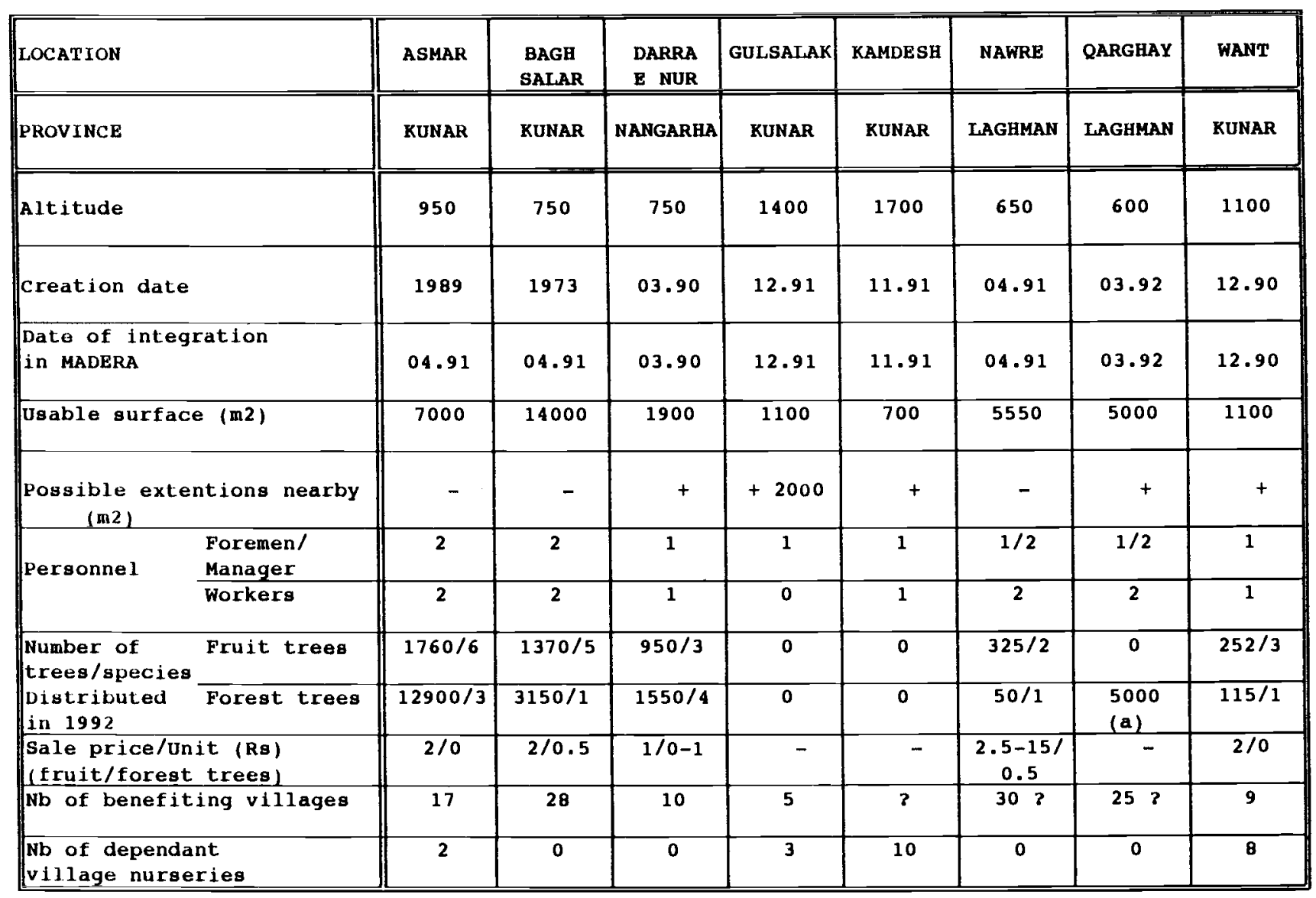

(a) 5000 poplars produced in BAGH SALAR but sent and distributed in QARGHAY

TABLE 1 :

MAIN CARACTERISTICS OF MADERA'S NURSERIES 
Seedlings:

Walnut...

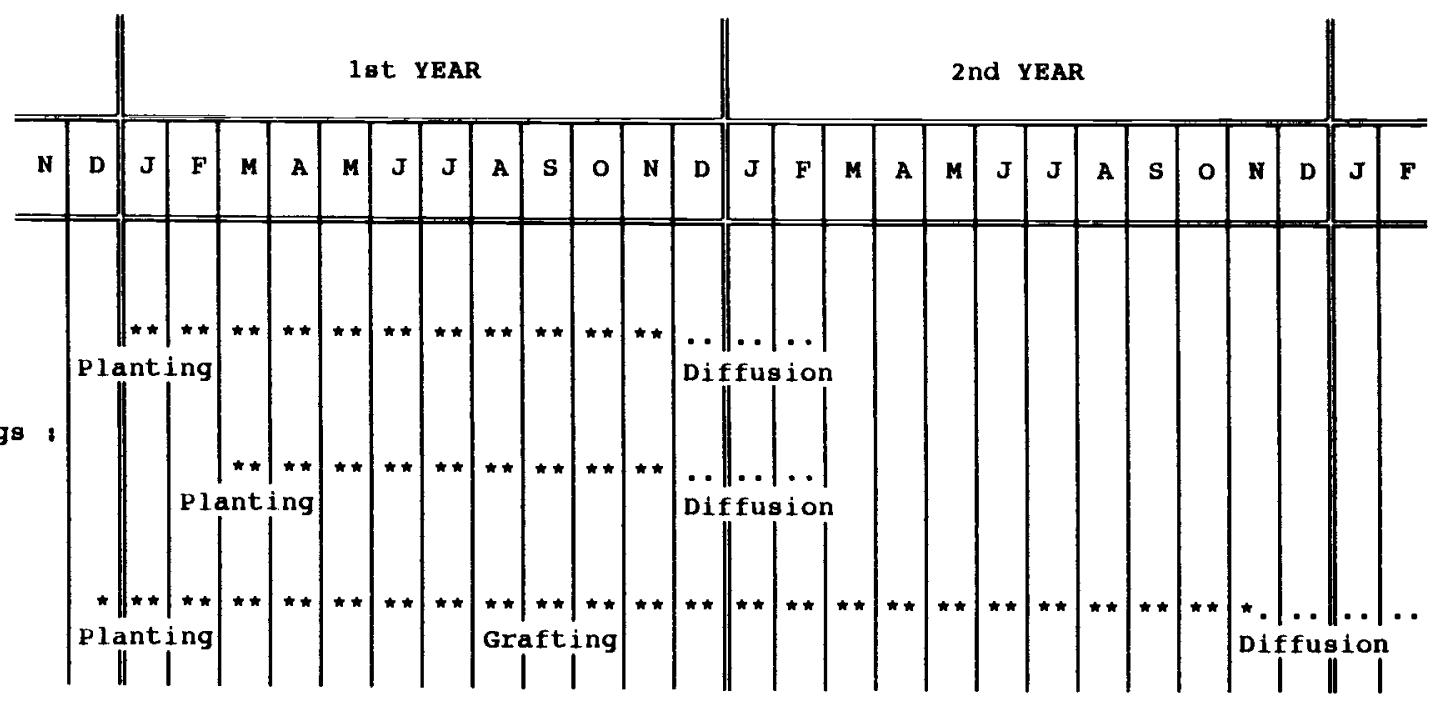

Grafted trees Apricot, Almond, Peach...

TABLE 2 :

PRODUCTION WORKPLAN FOR FRUIT TREES 


\begin{tabular}{|c|c|c|c|c|c|c|}
\hline & ASMAR & $\begin{array}{c}\text { BAGH } \\
\text { SALAR } \\
\end{array}$ & $\begin{array}{l}\text { DARRA } \\
\mathbf{E} \text { NUR } \\
\end{array}$ & NAWRE & WANT & TOTAL \\
\hline $\begin{array}{l}\text { ACACIA } \\
\text { NILOTICA }\end{array}$ & & & 20 & & & 20 \\
\hline CEDAR & & & & & 115 & 115 \\
\hline $\begin{array}{l}\text { EUCALYPTUS } \\
\text { CAMALD. }\end{array}$ & & & 20 & & & 20 \\
\hline $\begin{array}{l}\text { LEUCAENA } \\
\text { LEUCOCEPH. }\end{array}$ & 2000 & & & & & 2000 \\
\hline $\begin{array}{l}\text { BRAZ I LIAN } \\
\text { ROSEWOOD }\end{array}$ & & & 10 & & & 10 \\
\hline $\begin{array}{l}\text { POPLAR } \\
\text { DELTOIDES }\end{array}$ & 8000 & 3150 & & & & 11150 \\
\hline $\begin{array}{l}\text { BLACK } \\
\text { POPLAR }\end{array}$ & 2900 & & 1500 & & & 4400 \\
\hline TAMARISK & & & & 50 & & 50 \\
\hline TOTAL & 12900 & 3150 & 1550 & 50 & 115 & 17765 \\
\hline
\end{tabular}

TABLE 3 :

FOREST TREES DISTRIBUTED BY MADERA'S NURSERIES

IN 1992 


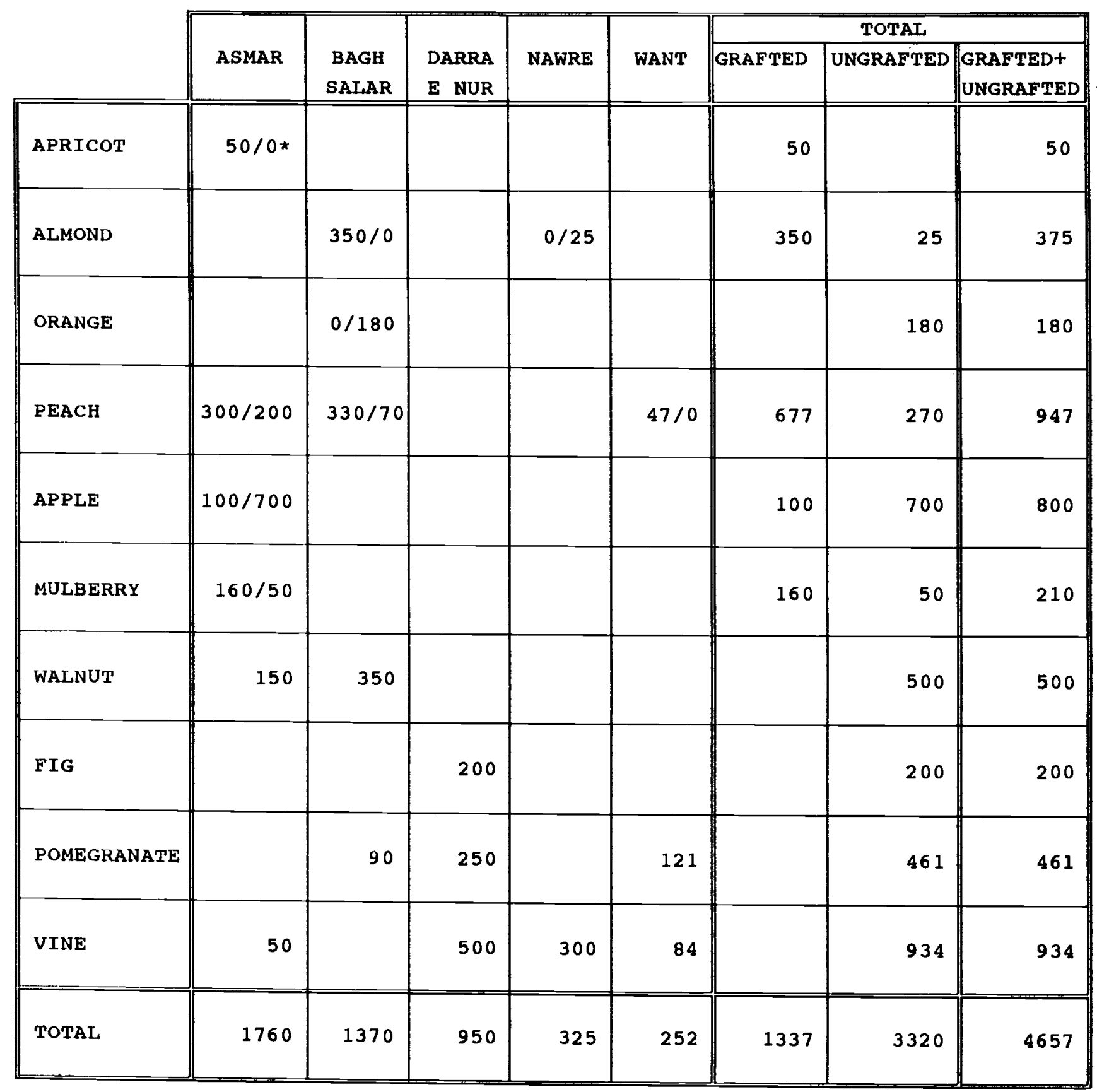

* Number of grafted/ungrafted trees

TABLE 4 :

FRUIT TREES DISTRIBUTED BY MADERA'S NURSERIES IN 1992 


\begin{tabular}{|c|c|c|c|c|c|c|c|}
\hline & & ASMAR & $\begin{array}{l}\text { BAGH } \\
\text { SALAR } \\
\end{array}$ & $\begin{array}{l}\text { DARRA } \\
\text { E NUR } \\
\end{array}$ & NAWRE & WANT & TOTAL \\
\hline \multicolumn{2}{|c|}{$\begin{array}{l}\text { Number of village } \\
\text { benefiting }\end{array}$} & 17 & 28 & 10 & 30 & 9 & 94 \\
\hline \multirow{2}{*}{$\begin{array}{l}\text { Forest } \\
\text { Trees }\end{array}$} & $\begin{array}{l}\text { total } \\
\text { distributed }\end{array}$ & 12900 & 3150 & 1550 & 50 & 115 & 17765 \\
\hline & $\begin{array}{l}\text { Average } \\
\text { per village }\end{array}$ & 758 & 112 & 155 & 1.6 & 12.7 & 189 \\
\hline \multirow{2}{*}{$\begin{array}{l}\text { Fruit } \\
\text { Trees }\end{array}$} & $\begin{array}{l}\text { total } \\
\text { distributed }\end{array}$ & 1760 & 1370 & 950 & 325 & 252 & 4657 \\
\hline & $\begin{array}{l}\text { Average } \\
\text { per village }\end{array}$ & 103 & 49 & 95 & 10.8 & 28 & 49.5 \\
\hline
\end{tabular}

TABLE 5 :

AVERAGE NUMBERS OF TREES PER VILLAGE

DISTRIBUTED FROM MADERA'S NURSERIES IN BEGINNING 1992 


\begin{tabular}{|c|c|c|c|c|c|c|c|c|c|}
\hline & ASMAR & $\begin{array}{l}\text { BAGH } \\
\text { SALAR } \\
\end{array}$ & $\begin{array}{l}\text { DARRA } \\
\text { E NUR } \\
\end{array}$ & GULSALAK & KAMDESH & NAWRE & QARGHAY & WANT & TOTAL \\
\hline Acacia nilotica & 200 & 2000 & 1000 & & & & & 3600 & 6800 \\
\hline Ail anthus & 2000 & 1500 & 1000 & & & & & 1400 & 5900 \\
\hline Eucalyptus camald. & 3500 & 25000 & 2000 & & & 500 & & 3400 & 34400 \\
\hline Leucaena leucoceph. & 500 & 7000 & 1000 & & & & & 300 & 8800 \\
\hline Poplar alba & & 3000 & & & & & & & 3000 \\
\hline Poplax deltoides & & & & & & & 1400 & & 1400 \\
\hline Poplar nigra & 700 & & 500 & 150 & 240 & & & & 1590 \\
\hline Poplar hybrid & & & & & & & & & 0 \\
\hline Robinia & & 6000 & 1000 & & & & & 1800 & 8800 \\
\hline Sesbania & 300 & & & & & & & & 300 \\
\hline TOTAL FOREST I'REES & 7200 & 44500 & 6500 & 150 & 240 & 500 & 1400 & 10500 & 70990 \\
\hline Loguat tree & & & & & & 250 & & & 250 \\
\hline Walnut & 205 & 1080 & 475 & 435 & 95 & 340 & 220 & & 2850 \\
\hline Fig & & & 225 & 200 & & & 300 & & 725 \\
\hline Pomegranate & & & 490 & 230 & & & 200 & & 920 \\
\hline Vine & 175 & & 540 & 345 & 625 & 100 & 100 & & 1885 \\
\hline TOTAL FRUIT TREES & 380 & 1080 & 1730 & 1210 & 720 & 690 & 820 & & 6630 \\
\hline GRAND TOTAL & 7580 & 45580 & 8230 & 1360 & 960 & 1190 & 2220 & 10500 & 77620 \\
\hline
\end{tabular}

TABLE 6 :

ESTIMATED AMOUNT OF TREES READY FOR DISTRIBUTION IN BEGINNING 1993 


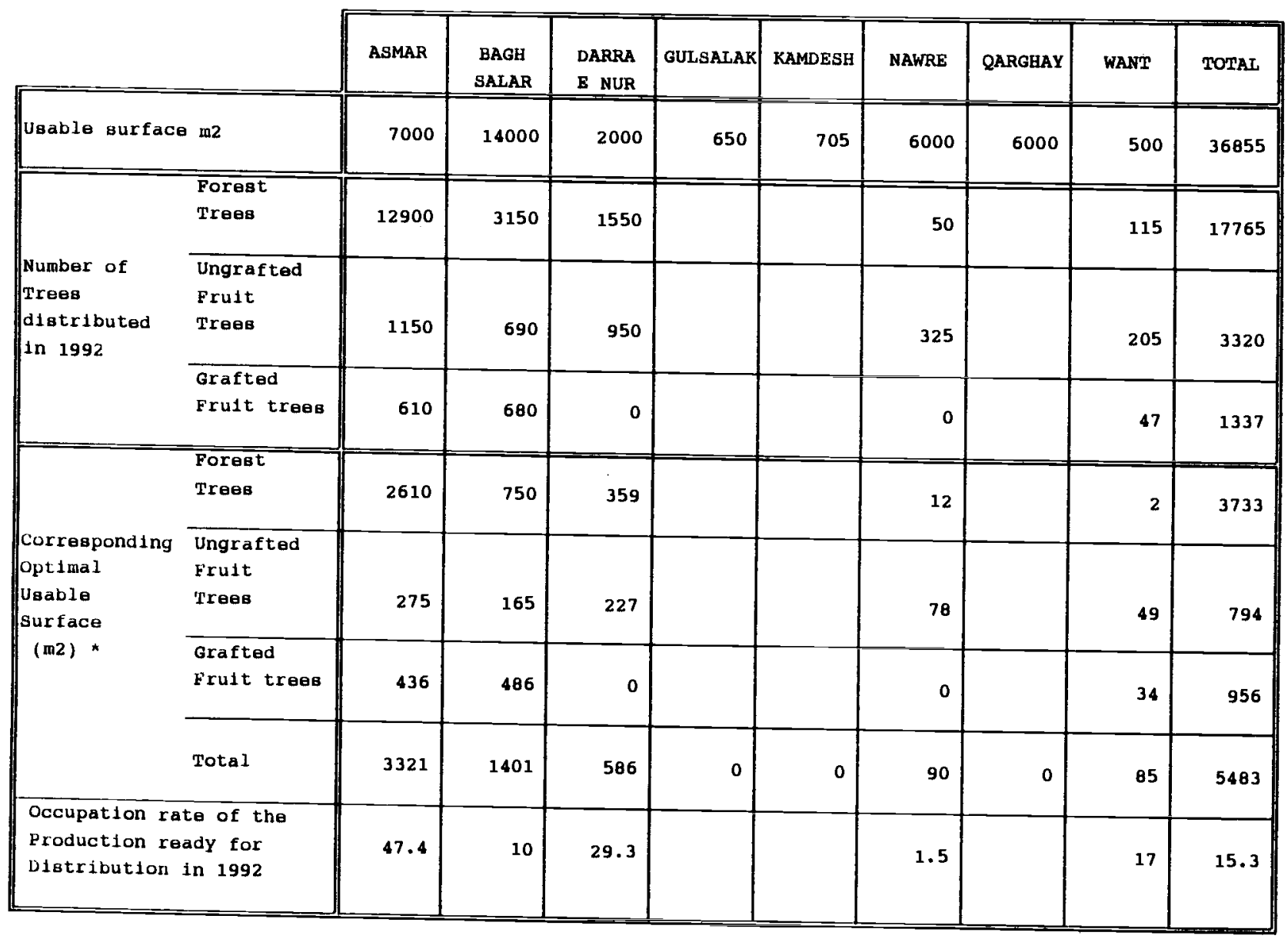

A Optimal aurfaces are computed according to the following normes :

- Poplars and tamarisk : produced in 1 year, 8400 unıts/usable jerib

- Cedars : produced 1n 2 years in plastic bags, 1000 units/7 m²

TABLE 7 A :

1991 OCCUPATION RATE

OF THE TREES DISTRIBUTED IN SPRING 1992 


\begin{tabular}{|c|c|c|c|c|c|c|c|c|c|c|}
\hline & & ASMAR & $\begin{array}{c}\text { BAGH } \\
\text { SALAR } \\
\end{array}$ & $\begin{array}{l}\text { DARRA } \\
\text { E NUR } \\
\end{array}$ & GULSALAK & KAMDESH & NAWRE & QARGHAY & WANT & TOTAL \\
\hline \multirow{3}{*}{$\begin{array}{l}\text { Number of } \\
\text { Trees to be } \\
\text { distributed } \\
\text { in } 1993\end{array}$} & $\begin{array}{l}\text { Forest } \\
\text { Trees }\end{array}$ & 7200 & 44500 & 6500 & 150 & 240 & 500 & 1400 & 10500 & 70990 \\
\hline & $\begin{array}{l}\text { Ungrafted } \\
\text { Frult } \\
\text { Trees }\end{array}$ & 380 & 1080 & 1730 & 1210 & 720 & 690 & 820 & 0 & 6630 \\
\hline & $\begin{array}{l}\text { Grafted } \\
\text { Fruit trees }\end{array}$ & & & & & & & & & \\
\hline \multirow{4}{*}{$\begin{array}{l}\text { Corresponding } \\
\text { Opt1mal } \\
\text { Usable } \\
\text { Surtace } \\
(\mathrm{m} 2) \star\end{array}$} & $\begin{array}{l}\text { Forest } \\
\text { Trees }\end{array}$ & 213 & 1006 & 161 & 36 & 58 & 4 & 334 & 74 & 1886 \\
\hline & $\begin{array}{l}\text { Ungrafted } \\
\text { Fruit } \\
\text { Irees } \\
\end{array}$ & 91 & 258 & 412 & 297 & 172 & 165 & 196 & 0 & 1591 \\
\hline & $\begin{array}{l}\text { Grafted } \\
\text { Fruit trees }\end{array}$ & & & & & & & & & \\
\hline & Total & 304 & 1264 & 573 & 333 & 230 & 169 & 530 & 74 & 3477 \\
\hline \multicolumn{2}{|c|}{$\begin{array}{l}\text { Occupation rate of the } \\
\text { Production ready for } \\
\text { Distribution in } 1993\end{array}$} & 4.3 & 9 & 28.7 & 51.2 & 32.6 & 2.8 & 8.8 & 14.8 & 9.7 \\
\hline
\end{tabular}

* Cf note table 7 A

TABLE 7 B :

1992 OCCUPATION RATE

OF THE TREES READY FOR DISTRIBUTION IN SPRING 1993 


\begin{tabular}{|c|c|c|c|c|c|c|}
\hline & \\
\hline & & ASMAR & BAGH SALAR & KAMDESH & WANT & TOTAL \\
\hline \multicolumn{2}{|l|}{ Total, Direct Costs } & 223265 & 237895 & 57015 & 62240 & 580415 \\
\hline \multicolumn{2}{|l|}{ Iotal, Investments } & 13520 & 13520 & 7160 & 7160 & 41360 \\
\hline \multirow{3}{*}{$\begin{array}{l}\text { eroduction expenses } \\
\text { for year } 1992 \\
\text { (for distribution } \\
\text { in beginning of } 93 \text { ) }\end{array}$} & $\begin{array}{l}\text { Yearly investments } \\
\text { (redemption) }\end{array}$ & 2700 & 2700 & 1430 & 1430 & 8260 \\
\hline & Running costs & 209745 & 224375 & 49855 & 55080 & 539055 \\
\hline & Total & 212445 & 227075 & 51285 & 56510 & 547315 \\
\hline \multirow{3}{*}{$\begin{array}{l}\text { Number of trees } \\
\text { produced in } 92 \text { for } \\
\text { distribution } \\
\text { in spring } 1993\end{array}$} & Forest trees & 7200 & 44500 & 240 & 10500 & 62440 \\
\hline & Fruit trees & 380 & 1080 & 720 & 0 & 2180 \\
\hline & Total & 7580 & 45580 & 960 & 10500 & 64620 \\
\hline \multirow{3}{*}{$\begin{array}{l}\text { Production } \\
\text { Costs }\end{array}$} & Average per tree (1) & 28 & 5 & 53.5 & 5.5 & 8.5 \\
\hline & of a forest tree (2) & 24.5 & 4.5 & 16.5 & 5.5 & 7.5 \\
\hline & of a fruit tree (2) & 97.5 & 18.5 & 66 & 0 & 31 \\
\hline
\end{tabular}

(1) Whatever the tree

(2) Fruit trees production is considered as 4 times more expensive than forest trees one

TABLE 8 :

ESTIMATED EXPENSES FOR YEAR 1992 AND COST PRICE OF THE TREES 


\begin{tabular}{|c|c|c|c|c|c|c|c|c|}
\hline & \multicolumn{4}{|c|}{ FORES'T TREES } & \multicolumn{3}{|c|}{ FRUIT TREES } & \multirow{2}{*}{$\begin{array}{l}\text { GRAND } \\
\text { TOTAL }\end{array}$} \\
\hline & $\begin{array}{l}\text { poplar } \\
\text { (a) }\end{array}$ & $\begin{array}{c}\text { Eucalyptus } \\
\text { (b) }\end{array}$ & $\begin{array}{c}\text { other } \\
\text { species } \\
\text { (b) } \\
\end{array}$ & Total & Grafted & $\begin{array}{l}\text { Ungrafted } \\
\text { (a) }\end{array}$ & Total & \\
\hline $\begin{array}{l}\text { Number of trees } \\
\text { produced per } \\
\text { year }\end{array}$ & 4200 & 30000 & 30000 & 64200 & $\begin{array}{l}9000 \text { (c) } \\
6000 \text { (d) }\end{array}$ & 5420 & $\begin{array}{l}14420 \\
11420\end{array}$ & $\begin{array}{l}78620 \\
75620\end{array}$ \\
\hline $\begin{array}{l}\text { Occupied usable } \\
\text { surface }(\mathrm{m} 2)\end{array}$ & 1000 & 210 & 210 & 1420 & 4290 & 1290 & 5580 & 7000 \\
\hline
\end{tabular}
(a) Trees produced in 1 year, 8400 units/ usable jerib/year
(b) Trees produced in 1 year, 1000 units on $7 \mathrm{~m} 2$
(c) Trees produced in 2 years, 4200 units/usable jerib/year (distribution in the fall of 2 nd year).
(d) Trees produced in 2 years and 2 to 4 months, 2800 units/usable jerib/year (distribution in the spring of 3 rd year).

TABLE 9 :

EXAMPLE OF A PRODUCTION PLAN FOR A 7000 usable m2 NURSERY 


\begin{tabular}{|c|c|c|c|c|}
\hline & STAFF & $\begin{array}{c}\text { USABLE } \\
\text { SURFACE (m2) } \\
\end{array}$ & $\begin{array}{c}\text { SURFACE/STAFF } \\
(\mathrm{m} 2)\end{array}$ & $\begin{array}{l}\text { OCCUPATION RATE } \\
\text { OF THE STAFF \& * }\end{array}$ \\
\hline ASMAR & 3 & 7000 & 2335 & 46.7 \\
\hline BAGH SALAR & 3 & 14000 & 4665 & 96.3 \\
\hline DARRA E NUR & 1.5 & 1900 & 1265 & 25.3 \\
\hline GULSALAK & 0.5 & 1100 & 2200 & 44.0 \\
\hline KAMDESH & 1.5 & 700 & 465 & 9.3 \\
\hline NAWRE & 2 & 5550 & 2775 & 55.5 \\
\hline QARGHAY & 2 & 5000 & 2500 & 50.0 \\
\hline WANT & 1.5 & 1100 & 735 & 14.7 \\
\hline TOTAL & 15 & 36350 & 2425 & 48.5 \\
\hline
\end{tabular}

* In comparison with a standard of 1 worker for $5000 \mathrm{~m} 2$

TABLE 10 :

STAFF COMPARED TO SURFACE IN MADERA'S NURSERIES 


\begin{tabular}{|c|c|c|c|}
\hline & & A & B \\
\hline \multirow{3}{*}{$\begin{array}{l}\text { Trees } \\
\text { Annual } \\
\text { Output }\end{array}$} & Forest trees & \multicolumn{2}{|c|}{64200} \\
\hline & $\begin{array}{l}\text { Grafted } \\
\text { Fruit Trees (a) }\end{array}$ & \multicolumn{2}{|c|}{9000} \\
\hline & $\begin{array}{l}\text { Ungrafted } \\
\text { Fruit Trees }\end{array}$ & \multicolumn{2}{|c|}{5420} \\
\hline $\begin{array}{l}\text { Annual expenses (A) } \\
\text { or } \\
\text { Annual income (B) }\end{array}$ & & 161445 & 170460 \\
\hline \multirow{3}{*}{$\begin{array}{l}\text { Cost price (A) } \\
\text { or } \\
\text { selling price (B) }\end{array}$} & of a Forest Tree & 1.35 (b) & 1 \\
\hline & $\begin{array}{l}\text { of an Ungrafted } \\
\text { Fruit Tree }\end{array}$ & \multirow{2}{*}{5,3 (b) } & 3 \\
\hline & $\begin{array}{l}\text { of a Grafted } \\
\text { Fruit Tree }\end{array}$ & & 10 \\
\hline
\end{tabular}

(a) 2 years trees

(b) Fruit trees production is considered as 4 times more costly than forest trees one.

\section{TABLE $11:$}

(A) COST PRICE OF TREES PRODUCED IN A NURSERY HAVING AN USABLE SURFACE OF $7000 \mathrm{~m} 2$, ACCORDING TO THE HYPOTHESIS FROM TABLE 10 AND THE 1992 EXPENSES IN ASMAR FROM TABLE 8. STAFF EXPENSES ARE ADAPTED TO THE STANDARD ACCORDING TO SURFACE.

(B) INCOME ACCORDING TO THE PROPOSED SET OF PRICES. 
ANNEX 4 : CHECKLIST FOR NURŚERY MANAGERS.

0.1 - Name of the nursery (location)

0.2 - Starting date

0.3 - Names of the nursery manager and of his staff

0.4 - Names of the benefiting villages

1 - Technical aspects

a) Creation of the nursery

1.1 - Why has this nursery been started?

1.2 - How and when were you selected to manage it ? What previous expérience did you have in this field? Did you follow some additional training from MADERA? Are you responsible for both production and distribution of the trees?

1.3 - Who was selected to work with you ? How was the staff recruited? How many staff is fulltime? How many temporary staff do you employ, and when/for what do you employ them? Are you satisfied with your staff?

1.4 - In which circomstances and with which criterias was the location of the nursery selected? By who? What is the land status (lessed/given...) ?

1.5 - Environmental caracteristics: site/ exposure/ altitude/ soil/ monthly mean of maximum and minimum temperatures/ precipitations/ water availability/ winds/ etc... Do you measure the climatic parameters and with what? According to you, is this location suitable?

1.6 - What is the usable surface of the nursery?

1.7 - Is there village nurseries from the forestry program of MADERA in the area? Where are they ? How many years have they been working? What are they producing and distributing (species, quantities)? What are the other activities of the techniciens
in charge of them ?

1.8 - Do you have additional remargs on the location, organization or the fonctionment of the nursery? 
b) Trees production

1.9 - What are the most demanded species in the area? Why ? Why are others species in less demand?

1.10 - Which local and foreign species have been multiplied in your nursery? For what use (timber, fire wood, fruits, ornemental)

1.11 - What multiplication techniques do you use : seedlings (in bags, in plain ground) ; cuttings, others ? Who does the practical work? Can you and your staff graft?

1.12 - Do you prospect the region to find interesting local species and varieties for vegetative or sexual multiplication ? Have you done production trials in the area? Is there a collection of mother plants in the area? Where? Who started it? When?

1.13 - Where do the cuttings and seeds that you plant come from? Did you face any difficulty to get them? 1.14 - For each species, how many seeds/bags/cuttings were planted
this year?

1.15 - Date of planting for each species?

1.16 - What shade and watering conditions were applied for each species?

1.17 - Did you submit any plot to a different set of conditions? Which one (soil, seed treatments, watering, etc...)? What were the results? Or are all species treated the same way (same soil, same bags, same watering...) ?

1.18 - What are the germination rate per species ? What are the mortality rates per species and per stage? What are the mortality main causes?

1.19 - Do you have peculiar problems, for which species $?$ What problems (low germinations, pests, animals, winds, weeds, lack of seeds, cuttings, rootstocks or scions, lack of water, tools or manure...) ?

1.20 - Which other operations were conducted during the cultivation period (prunning, root prunning, grafting...) ? When and how ? (per species).

1.21 - How many trees per species were avallable for the last distribution campaign?

1.22 - Do you have additional remarqs on trees production? 


\section{c) Distribution}

1.23 - What are the age and size of the trees when you distribute them ?

1.24 - How do you share out among the interested villages or people ?

1.25 - Number of trees distributed per year and species : grafted or ungrafted, from the nursery and from direct supply of FAO.

1.26 - Number of beneficiaries per village, average number of trees per beneficiary (total and per species). Estimate of the percentage of benefiting families among all local families.

1.27 - who are the beneficiaries? (land owners, internal refugees...)?

1.28 - Which people are not or less interested? How do you explain this attitude? Is there whole villages which are not interested and why ? (unadapted species, lack of suitable land, practices or traditions not favorable...)

1.29 - Did farmers from another zone contacted you to get trees? How many farmers? Did you give trees to them?

1.30 - When do you distributed trees (for each species: starting and ending date). If it is a long process, why?

1.31 - Do you register you beneficiaries with the date and numbers of trees per species?

1.32 - Is there too much or too less trees compared to demand (per species) ? Why ? Did you give or import trees from other nurseries or NGOs (total amount per species)? How much was the demand per species?

1.33 - Have any trees been produced or distributed by others than MADERA ? BY who ? (private trees growers, NGOs, tradespeople) Origin, prices and qualities (per species).

1.34 - Is there a lot of farmers which produce trees for their own use ?

1.35 - How many trees will be distributed next year (per species and origin (from this nursery, another one or FAO...) ?

1.36 - Do you have additional remarqs on distribution? 
d) Plantation

1.37 - How long does it take for the trees to get planted after leaving the nursery? If it is long, why?

1.38 - Kinds of plantations, villages, techniques and by who?

1.39 - Average survival rate per species? If low, why?

1.40 - Do you replace the trees that died after plantation?

1.41 - Do you have additional remargs on plantations?

\section{e) Extension and follow up}

1.42 - Is there double cropping in the area? Rainfed cropping ? Do farmers use animal manure in the fields ? Is there people having less or no land (percentage) ?

1.43 - In the population, is there farmers having experience in multiplication and plantation of trees? Who ? Which species? How ?

1.44 - Did you teach the farmers how to plant trees ? Do you advise them on the suitable species for a particular altitude and exposure? Do you advise them on the place and the techniques of planting, the follow up, the use of fertilizers and pesticides (do you provide any of them ?), the harvest, storage and sale ...?

1.45 - Do you teach them on an individual basis or collectively? Where do you teach?

1.46 - Do you respond to particular needs on specific subjects or do you apply a global extension program? From the training branch of MADERA ? Using other MADERA technicians?

1.47 - What medium do you use to convey technical advices (speeches, writings, images, audio-visual methods) ?

1.48 - Did you organize demonstrations (plantation, grafting...) ? Farmers visits? What would you (or do you) show them?

1.49 - Do you follow up plantations ? Do you visit farmers plantations? What is the frequency of your visits? Did you notice mistakes? Which ones? Did you make observations on the behavior and adaptation of the species or varieties produced in the nursery? What are the results of these observations?

1.50 - Who is benefiting from your extension work? What percentage of the people receiving trees? 
1.51 - Do you feel that the beneficiariès have sufficient knowledge and practice on arboriculture?

1.52 - Who couldn't you touch so far in your extension work? Why?

1.53 - Do you have additional remarqs on extension?

\section{$\underline{\underline{2}}-$ Financial and economic aspects}

2.1 - Do you know the overall cost for the functionment of this nursery? How much is it?

2.2 - Collection of this information in Peshawar :

* Rent of land

* Cost of the water schemes

* " " land preparation

* " " seeds

* " " plastic bags

* " " other materials

* " labour (permanent/part time)

* transportation costs

* Salaries for management staff

2.3 - Calculation of the price cost of trees

2.4- How much do you sell your trees (per species)?

2.5 - How was this prices decided ? Are they incentive or prohibitive for farmers?

2.6 - If you replace trees which died after plantation, do you do it free of cost?

2.7 - Do you have other incomes than trees sale?

2.8 - Total income from trees sale this year?

2.9 - How did you use this income (precise spendings) ? How much did you send to Peshawar? When ?

2.10 - Estimate of the surface planted with trees from the nursery (per village).

2.11 - What is the purpose of these plantations for the farmers (self consomption, sale)? When will these plantations produce and how much will the production be ?

2.12 - Which local products are currently commercialized and where?

2.13 - Is there, according to you, other local current productions which could be commercialized but are not so far?

2.14 - Do you have additional financial or economic remarqs? 


\section{3 - Local participation}

3.1 - Are the local people (or some of them, which ones) aware of a ecological damages such as deforestation, increasing scarcity of useful species, over-grazing, erosion, decrease in soil fertility, etc...?

3.2 - Is the local population able to indentify actions that needs to be done in this regard? Which ones?

3.3 - Are there collectives works or actions? Which ones ?

3.4 - Who decided that a nursery should be started here and how was it done? What were the needs that the nursery was to fulfil? Needs expressed by who?

3.5 - Did the local people (or some of them, which ones) participate in the implementation planning and process? (choice of the nursery location, implementation work, control and evaluation of the activities...) 3.6 - Do you feel that the local population approve what you are
doing and why? 3.7 - How to raise interest in those villages or persons not touched
so far?

3.8 - Do you have additional remarqs on local participation ?

\section{4 - Prospective aspects}

4.1 - How much of your time do you spend in nursery work? In paper work ? In extension work? In Peshawar? Do you feel that you can achieve these works in a succesful way?

4.2 - What is the content, the frequency and the destination of your reports? Where, when and for what do you meet with the geographical manager, with the technical manager, with other MADERA staff in Peshawar? Who do you work closely with?

4.3 - Is the technical process of trees production well mastered? If not, what are the main difficulties?

4.4 - Do you experiment, and what do you experiment ? (comparison of multiplication techniques/ behaviour trails/ others) Do you think that you need to improve your mother plants collection?

4.5 - Do you need more training for you or your staff? In which fields? Is there other ways to improve your efficiency? 
4.6 - On what base are the species and varieties selected for the current and future production plans ? Were the needs of the local population registered ? Do you take into account the trees mortality (in nursery/on plantation time) ?

4.7 - Are there demands for other species or kind of trees and plants (ornemental...) ? For other kinds of plantations (village woodlots, urban plantations) ?

4.8 - Do you feel that you need to broaden the choice of species, and how ?

4.9 - Are there many available sites for plantations ? Which ones?

4.10 - Do you feel that you have to better evaluate the needs in the future? To respond better on the quantitative side, the qualitative side?

4.11 - Is it possible to increase the retail price of the trees? Upto what level?

4.12 - According to you, how will the trees demand evolve in the future ? Why (refugees return, saturation, competition from other nurseries, new cash crops in the area, others...) ?

4.13 - Is the present surface of the nursery sufficient to respond to demand. If not, can the size of nursery be increased to fulfil demand? Or shall new nurseries be established ? Where?

4.14 - Do you think that coordination between nurseries is usefull? In which fields? Should they become more complementary, more specialized?

4.15 - Can the nursery play a role in the extension of vegetables production (seeds or seedlings multiplication, training)?

4.16 - What is the impact of village nurseries so far? How do you imagine they future?

4.17 - Can the nursery pay for itself, at what stage, under which conditions?

4.18 - Are some farmers able to run a nursery? Which techniques do they know well? Can they be trained on techniques they don't know? Who in particular?

4.19 - Can the nursery be take in charge by whole or a part of the local population? How to prepare this overtaking (negociations, training) ?

4.20 - Do you have other propositions? How to improve MADERA's work ? How to increase the autonomy of farmers in regards of trees production?

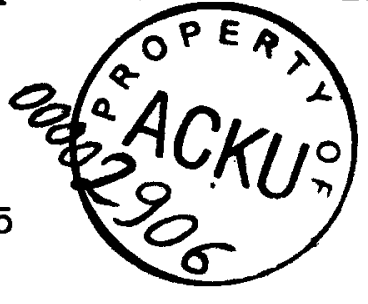

